\title{
The Early Music Collection of the Bibliotheca aulica Salisburgensis: An Initial Investigation*
}

\author{
Royston Gustavson
}

\section{Introduction}

The University Library of Salzburg, which holds much of the former Archiepiscopal Court Library of Salzburg (Bibliotheca aulica Salisburgensis, hereafter B.A.S.), contains almost no early polyphonic or instrumental music. Nevertheless, recent research has determined that until the nineteenth century, the B.A.S. included a corpus of printed and manuscript polyphony from the first half of the sixteenth century, much of it related in some way to the Salzburg composer and humanist Johannes Stomius. ${ }^{1}$ The present paper examines the dispersal of this collection, which began in the 1840 s, and traces the location of the identifiable polyphonic music books from the B.A.S. by following their transfer through the rare book trade in the nineteenth century. This process has resulted in the identification of an additional twenty-two printed editions, thereby increasing the total number of identified printed editions with a B.A.S. provenance from nine to thirty-one. The paper then, as far as currently possible, reconstructs and discusses the polyphonic music collection of the B.A.S.

Peter Mohr's study of the set of manuscript partbooks Reg I of the Proske collection in the Bischöfliche Zentralbibliothek, Regensburg, noted the B.A.S. shelfmark on those partbooks; it was known that the partbooks had been purchased from the Butsch Antiquariat in Augsburg, and so Mohr suggested that the shelfmark indicated that the partbooks were from the Sammlung Butsch in Augsburg. ${ }^{2}$ This continued to be regarded as a possible meaning of the shelfmark, including in Gertraut Haberkamp's thematic catalogue of sixteenth- and seventeenth-century manuscripts in the Proske

\footnotetext{
I am grateful to Grantley McDonald and Paul Kolb for inviting me to participate in their investigation of the Stomius manuscripts, and for their collegiality and insights throughout this project. I am indebted to Dr. Raymond Dittrich, Proskesche Musikabteilung, Bischöfliche Zentralbibliothek, Regensburg, for the generosity of his assistance during my visit to that library, for facilitating my acquisition of complete colour scans of the manuscripts B 211-215, B 216-219, and B 220-222 (henceforth Reg I, Reg II, and Reg III), for photographs of the binding of a number of items, and for answering several follow-up email questions.

1 This previously identified corpus consists of five manuscripts identified by Gertraut Haberkamp and Jochen Reutter, Bischöfliche Zentralbibliothek Regensburg: Thematischer Katalog der Musikhandschriften 2: Sammlung Proske: Manuskripte des 18. und 19. Jahrhunderts aus den Signaturen A.R., C, AN, Kataloge Bayerischer Musiksammlungen 14/2 (Munich, 1989) (henceforth Haberkamp and Reutter, Thematischer Katalog II) and nine printed editions: five identified in Haberkamp and Reutter, Thematischer Katalog II, three by me, and one by the team at the Verzeichnis deutscher Musikfrühdrucke / Catalogue of Early German Printed Music (henceforth vdm: <www.vdm.sbg.ac.at>). The $v d m$ identifies each early German music edition by a unique number, which is given in the format ' $v d m$ 1234'.

2 Peter Mohr, Die Handschrift B 211-215 der Proske-Bibliothek zu Regensburg mit kurzer Beschreibung der Handschriften B 216-219 und B 220-222, Schriften des Landesinstituts für Musikforschung Kiel 7 (Kassel, 1955), 19-20.
} 
collection. ${ }^{3}$ However, in the introduction to the thematic catalogue of eighteenth- and nineteenth-century manuscripts in the Proske collection (1989), Haberkamp and Reutter correctly identified that the B.A.S. shelfmark indicated the books came from the Bibliotheca aulica Salisburgensis. ${ }^{4}$ Until now, little has been known of the music collection of the B.A.S., and so this study of the collection will provide context for the articles by Grantley McDonald and Paul Kolb in the current issue of this Journal on the printed and manuscript music in Stomius' collection.

The bulk of the B.A.S. is now part of the University Library of Salzburg, and although numerous music treatises and liturgical books containing printed music are found today in the University Library, the only printed or manuscript polyphonic music remaining in the collection is an edition of homophonic ode settings that was not catalogued as music, and a single convolute of five superius partbooks identified as part of my investigation. ${ }^{5}$ This suggests that the polyphonic music was kept as a separate unit. This is consistent with what we know of the way musical materials were classified in the catalogues of sixteenth-century libraries and publishers. For example, in the 1560 catalogue of the publishers Montanus and Neuber, the section 'Musica libri' consisted solely of polyphonic music, with the music theory appearing under the heading 'Scholasticalia', and the liturgical books that included notated music being included in the general sections of the catalogue, classified by format and language. ${ }^{6}$ As almost no polyphonic music from the B.A.S. remains in Salzburg, and as no catalogues of the B.A.S. from before its dissolution in 1807 are known to survive, ${ }^{7}$ an understanding of the music collection must be reconstructed from other sources.

The immediately distinctive features of printed books and manuscripts that were in the B.A.S. are their spines and shelfmarks. Beatrix Koll has written that in the late seventeenth or early eighteenth century, the spines of the books in this collection were painted with a yellow-grey oil paint (now often faded to a dirty white), and inscribed with shelfmarks ending in 'B.A.S.' B.A.S. volumes also carried a second, different shelfmark, written on the front cover or front end-paper. Although this second shelfmark

\footnotetext{
Gertraut Haberkamp, Bischöfliche Zentralbibliothek Regensburg: Thematischer Katalog der Musikhandschriften I: Sammlung Proske: Manuskripte des 16. und 17. Jahrhunderts aus den Signaturen A.R., B, C, AN, Kataloge Bayerischer Musiksammlungen 14/1 (Munich, 1989), 204 (henceforth Haberkamp, Thematischer Katalog I).

4 Haberkamp and Reutter, Thematischer Katalog II, xxv.

5 For an overview of pre-16oo manuscript and printed music in Salzburg collections, see Salzburger Musikquellen bis 1600 at <https://w-k.sbg.ac.at/de/kooperationspartner/salzburger-musikquellen-bis-16oo.html> (accessed 11 November 2019). Music treatises that remain in the University Library of Salzburg include three titles in a convolute of four editions in upright octavo format: Johannes Stomius, Prima ad musicen instructio (Augsburg: Philipp Ulhart the Elder, 1537), $v d m$ 723, Johannes Stirpianus, Musicae planae rudimenta (Augsburg: Ulhart, c. 1553), and Johannes Cretz, Compendiosa introductio in choralem musicam (Augsburg: Ulhart, 1553), all with the B.A.S. shelfmark $\mathrm{S}_{\overline{3}} 30$ B.A.S., A-Su shelfmark 72484 I Rarum; in upright folio: Johannes Frosch, Rerum musicarum opusculum rarum ac insigne (Strasbourg: Peter Schöffer the Younger \& Matthias Apiarius, 1535), vdm 564, B.A.S. shelfmark AA2 72, A-Su shelfmark F II 359; and in upright quarto: Franchinus Gaffurius, Practica musice (Venice: Agostino Zanni, 1512), B.A.S. shelfmark illegible, A-Su shelfmark F II 475. Liturgical books containing printed music that remain in the University Library of Salzburg include $v d m$ 236, 253, 257, 263, 265, 485, and 581; of particular interest is an edition of the Liber canticorum (Nuremberg: Montanus \& Neuber, [c. 1548]), vdm 1125, which is in the convolute of four editions described earlier in this footnote with the B.A.S. shelfmark $\mathrm{S}_{\overline{3}} 30$ B.A.S., A-Su shelfmark 72484 I Rarum.

6 Royston Gustavson, 'The Montanus \& Neuber Catalogue of 1560', in Early Printed Music and Material Culture in Central and Western Europe, ed. Andrea Lindmayr-Brandl and Grantley McDonald, in press.

7 I am grateful to Beatrix Koll, Director of Special Collections at the University Library of Salzburg, for this information (email dated 23 October 2019).

8 Beatrix Koll, 'Universitätsbibliothek Salzburg. Geschichte der Sondersammlungen', <http://www.ubs.sbg.ac.at/sosa/ webseite/sosageschichte.htm> (accessed 15 July 2019).
} 
does not explicitly link the books to the B.A.S., almost all of the known books with this second shelfmark have a demonstrable connection with Salzburg, such as the watermarks of the end-papers, tools used in binding, and scribal hands, which combine to provide compelling evidence that this second shelfmark likewise belongs to the Salzburg collection. ${ }^{9}$ In addition to the manuscripts and printed books in the Bischöfliche Zentralbibliothek, Regensburg, volumes from the B.A.S. have been previously identified in two other libraries. In my 1998 dissertation, I noted that the three-volume Formschneider edition of the Choralis Constantinus in the British Library carries the same white painted spine and type of B.A.S. shelfmark as the Formschneider Novum et insigne opus musicum in Regensburg, which indicates that both have the same provenance. ${ }^{10}$ Most recently, the $v d m$ project team noted the presence of a B.A.S. exemplar of Walther's Geistliche Gesangbüchlin in the Österreichische Nationalbibliothek. ${ }^{11}$ This information, combined with my search for additional B.A.S. material in those and other libraries, allows for an initial overview of the B.A.S. music collection.

The following brief account of the history of the B.A.S. is drawn from that by Karl Foltz, unless stated otherwise. ${ }^{12}$ The library was founded in 1672 from the libraries of Salzburg archbishops, and the books were ordered and catalogued by the first librarian, Johann Baptist Preschern, who compiled the now lost Catalogus librorum in bibliotheca veteri aulica existentium, collectus anno a partu virgineo $1672 .{ }^{13}$ The next catalogue was prepared some time between 1709 and 1727. A new catalogue was commenced by Florian Dalham (1713-95) but not completed, owing to his illness and death. ${ }^{14}$ From 1801 , as a result of the Napoleonic wars and their consequences, the collection lost many important volumes: some items were requisitioned by Paris, and in 1806 many books and manuscripts-approximately a twelfth of the collection-were requisitioned by Vienna. In 1807, a large part of the B.A.S. came to what is now the University Library of Salzburg, and was housed in the Bibliotheksaula. In 1815, twenty-seven manuscripts and 108 printed books were requisitioned and taken to the Royal Library in Munich. Two points can be made about Foltz's history. Firstly, the requisitioned items were all carefully selected for inclusion in other collections; and secondly, none of the material taken into those collections is known to have included any polyphonic music. As such, there is no reason to believe that any polyphonic music had been removed from the B.A.S. as a result of these political upheavals. Yet the polyphonic music collection was removed and next appeared, not in a great library, but in the shop of an Augsburg rare book dealer in 1845 .

There is no evidence for how the music left the collection, but the history of the University Library of Salzburg, as described in the Fabian Handbuch, is suggestive. ${ }^{15}$

\footnotetext{
9 Haberkamp and Reutter, Thematischer Katalog II, xxvi, state that the connection is questionable, but they were unaware of any B.A.S. music editions other than those in the Bischöfliche Zentralbibliothek.

10 Royston Gustavson, 'Hans Ott, Hieronymus Formschneider, and the Novum et insigne opus musicum (Nuremberg 1537-1538)' (Ph.D. diss., University of Melbourne, 1998), 394, n. 54, and 810.

$11 \quad v d m 1149$.

12 Karl Foltz, Geschichte der Salzburger Bibliotheken (Vienna, 1877), 66-77.

13 On Preschern, see Peter von Radics, 'Die Dismas-Brüder im XVII. und XVIII. Jahrhundert: Ein Beitrag zur Culturgeschichte Krains', in Blätter aus Krain (Beilage zur Laibacher Zeitung), 8/14 (9 April 1864), 54-55.

14 Franz Michael Vierthaler, Reisen durch Salzburg (Salzburg, 1799), 98; the Hofbibliothek is discussed at length on 93136. Further on Dalham, see Klement Alois Bader, Das gelehrte Baiern oder Lexikon aller Schriftsteller, welche Baiern im achtzehnten Jahrhundert erzeugte oder ernährte, vol. 1 (Nuremberg, 1804), cols. 208-9.

15 The following history is summarized from Lotte Riedlsperger and Diana McCoy, 'Universitätsbibliothek Salzburg: Hauptbibliothek', in Fabian Handbuch: Handbuch der historischen Buchbestände in Deutschland, Österreich und Europa
} 
Although the B.A.S. was absorbed into the University Library in 1807 , in 1810 the Bavarian government dissolved the University and in 1811 reinstituted it as a Lyceum (an institution of higher education lacking the right to award doctorates) that taught theology and philosophy, and medicine and surgery. The former university library was then given the status of a 'Lyceum library', headed by Judas Thaddäus Zauner, who immediately commenced work on an eleven-volume library catalogue of the printed volumes (that is, excluding manuscripts). ${ }^{16}$ In 1826 , the library became the 'Salzburger Studienbibliothek' and, according to the Fabian Handbuch, 'commenced a period of stagnation that lasted until the re-founding of the University in $1962 .{ }^{17}$ During this period, further cataloguing was undertaken; in 1833, a Catalogus Bibliothecae Salisburgensis was begun, which by 1892 consisted of a nine-volume author catalogue and a forty-one-volume subject catalogue. ${ }^{18}$ The Handkataloge contain sixteen entries relating to music theory, music dictionaries, and music journals, all of which were published between 1752 and 1845; there are no editions of music. ${ }^{19}$ Although there is no evidence, it is possible that, during this cataloguing, material that was not regarded as needed was sold.

One other Salzburg catalogue is important for our understanding of the music holdings of the B.A.S. In 1874, in the first instalment of his Chronik des Gesanges und der Musik in Salzburg, Alois Josef Hammerle cited a special index in the Studienbibliothek that listed all practical and theoretical music works up to 1874-approximately 500 in total-and appears to have transcribed all entries in the index and commented on many of them. ${ }^{20}$ This index gives us important clues about the B.A.S. and helps us identify what of it remained in Salzburg in 1874.

\section{B.A.S. Music Remaining in the Studienbibliothek}

Hammerle's study shows us the great B.A.S. riches in the area of music theory which, in addition to the extant items, included items no longer catalogued in the University Library of Salzburg, such as Veit Bild's Stella musicae (Augsburg: Öglin, 1507) [B.A.S. $\mathrm{AA}^{2}{ }_{157}$ ], or Georg Rhau's Enchiridion utriusque musicae practicae (Leipzig: Valentin Schumann, 1520) [B.A.S. $\left.S_{\overline{3}} 31\right] .{ }^{21}$ However, it is the two extant editions of polyphonic music that are of interest here. The first is the Harmoniae poeticae Pauli Hofheimeri (Nuremberg: Petreius, 1539) [RISM 153926]. The B.A.S. had two exemplars of this edition

(Hildesheim 2003), <https://fabian.sub.uni-goettingen.de/fabian?Universitaetsbibliothek_Salzburg_-Hauptbibliothek> (accessed 12 March 2020).

16 This catalogue was prepared between 1811 and 1815 (A-Su M II 37 to M II 44, M II 48, M III 120, and M III 121), each volume devoted to a single discipline. Unfortunately, an examination of this catalogue could not be undertaken within the current scope of this project.

17 Riedlsperger and McCoy, 'Universitätsbibliothek Salzburg', section 1.5.

18 See <https://ubsearch.sbg.ac.at/permalink/f/16hc907/USB_alma21110939740003341> (accessed 25 May 2019).

19 I am grateful to Beatrix Koll for a list of music-related editions from vol. 4, 'Mathematik, Oeconomie, Medicin, Naturgeschichte, Literatur- und Kunstgeschichte, Alterthumskunde', of the five-volume handwritten catalogue, 'Handkataloge der Salzburger Studienbibliothek aus dem Anfang des 19. Jahrhunderts' (email dated 21 November 2019); see also <https://ubsearch.sbg.ac.at/permalink/f/16hc907/USB_alma21161917100003341> (accessed 25 May 2019).

20 Alois Josef Hammerle, Chronik des Gesanges und der Musik in Salzburg: Beiträge zur Geschichte und Statistik dieses Landes nebst biographischen Notizen salzburgischer Musiker und Sänger I (Salzburg, 1874), [II]-III (Salzburg, 1876), all continuously paginated, with the reference to the index on 49 and the listing and discussion of its contents on 50-178. I do not know whether or not the original index is still extant.

${ }_{21}$ See also the titles listed in n. 5 above. 
that are extant: B.A.S. AA 158, now in the University Library of Salzburg [I 2369 Rarum], is still complete; but the exemplar now in the Bischöfliche Zentralbibliothek, Regensburg [B 286-290], has only two partbooks, B.A.S. $S_{\overline{3}} 60$ (alta vox) and B.A.S. $S_{\overline{3}} 62$ (infima vox), and is missing the suprema vox, the media vox, and the Introduction ('Libellus'). Hammerle (58-60) lists two exemplars: the complete exemplar still in Salzburg, and an incomplete exemplar comprising only two partbooks. One of these had the shelfmark as B.A.S. $S_{\overline{3}} 61$, while the shelfmark on the other was illegible; furthermore, he notes that the media vox and Introduction were bound together. Clearly, the set with the $S_{\overline{3}}$ shelfmark had become split at some point before Hammerle undertook his study, with two of the four partbooks making their way to Butsch and from him to Proske, and two remaining in Salzburg; those latter partbooks are no longer in the University Library catalogue and so must be regarded as missing.

Of greatest interest is Hammerle's entry on p. 62: a single B.A.S. convolute, now in the University Library of Salzburg with the shelfmark I 72445 Rarum. This is a convolute containing the superius partbooks of vols. 1, 2, 4, and 5, and the superius/tenor partbook of vol. 3 of the Chansons anciennes, published in Paris by Du Chemin in 155051. Like the Hofhaimer set, the partbooks remaining in Salzburg had become separated from the rest of their set by the time Hammerle saw them. As this convolute has since been rebound, Hammerle provides our only evidence that it is from the B.A.S. ${ }^{22}$ According to both RISM ${ }^{23}$ and Lesure and Thibault's bibliography of the editions of Du Chemin, the superius partbook for vols. 1, 2, and 4, and the superius/tenor partbook for vol. 3, are not extant; ${ }^{24}$ these partbooks are therefore a significant addition to the literature. It is important to note the layout of Du Chemin's editions, as will become evident later in this paper. Each of the first, second, and fourth volumes of Chansons anciennes was printed in two editions, one as a single book in choirbook format, and the other as a set of four partbooks. The third volume was also printed in two editions, one as a single book in choirbook format, but the other as a set of two (not four) partbooks, one containing the superius and tenor on facing pages, and the other containing the contratenor and bassus on facing pages. When the five volumes of the partbook edition of the Chansons anciennes held by the B.A.S. were bound together, the superius partbook contained vols. 1-5 of the superius voice plus vol. 3 of the tenor voice; and the contratenor contained vols. 1-5 of the contratenor voice plus vol. 3 of the bassus voice. As such, the tenor and bassus partbooks of this set each contained only vols. 1, 2, 4, and 5 .

\section{The Dispersal of the B.A.S. Music Collection}

The evidence presented below suggests that all currently identified music from the B.A.S. (apart from the individual partbooks discussed above), and probably all the music which

${ }^{22}$ I am grateful to Beatrix Koll for the information that the convolute was rebound.

${ }_{23} \mathrm{I}=\mathrm{RISM} 1551^{15}$ (lists altus and tenor as extant), II = RISM $1551^{6}$ (lists altus, tenor, and bassus as extant), III is an edition not listed in RISM ( $1550^{8}$ is a single volume in choirbook format); IV = RISM $1551^{8}$ (lists altus and tenor as extant), $\mathrm{V}=\mathrm{RISM} \mathrm{J} 449$ (lists superius and tenor as extant).

${ }^{24}$ François Lesure and Geneviève Thibault, 'Bibliographie des éditions musicales publiées par Nicolas du Chemin (15491576)', in Annales musicologiques 1 (1953), 269-373; 4 (1956), 251-53; and 6 (1958-63), 403-6; I = No. 20 (p. 302), II = No. 21 (pp. 302-3); III = No. 15 (pp. 298-99), IV = No. 23 (pp. 303-4), and V = No. 24 (p. 304). 
has not yet been identified, was acquired by the antiquarian bookseller Fidelis Butsch in Augsburg, and that he began selling it in 1845. There is no evidence as to how or from whom he acquired it.

Fidelis Butsch, born in 1805 in Würmlingen, arrived in Augsburg in 1835 and worked in Wilhelm Birett's antiquarian bookshop, which he purchased in 1839 from Birett's widow; in 1863, Butsch's son, Albert Fidelis Butsch (1839-1917) took over the business. ${ }^{25}$ Kocher-Benzing has written that Butsch soon developed the business into one of the leading antiquarian booksellers of its time, specializing in valuable early editions; he is famous for his 1858 auction of the duplicates of the Royal Library in Munich, including a forty-two-line Gutenberg Bible. ${ }^{26}$ The Butsch Antiquariat would have been an obvious choice for the sale of a collection of rare early music editions. ${ }^{27}$ His reputation for dealing in early musical materials continued; the fifteenth- and sixteenth-century music manuscripts that passed through his hands include three purchased by the Königliche öffentliche Bibliothek, Dresden, in 1858 (now D-Dl 1/D/2, $1 / \mathrm{D} / 3$ and $1 / \mathrm{D} / 4)^{28}$

\section{Acquisitions by the k. k. Hofbibliothek (now the Österreichische Nationalbibiothek, Vienna) ${ }^{29}$}

On 5 November 1845, Fidelis Butsch wrote to Anton Schmid, Custos (Director) of the k. k. Hofbibliothek (hereafter Hofbibliothek) in Vienna, enclosing a handwritten catalogue which listed the early theoretical and practical music editions he had for sale, but which did not include any prices. ${ }^{30}$ Although the catalogue is not extant (Butsch explicitly requested that it be returned to him), it was clearly very substantial, as the item numbers referred to in the correspondence reached up to No. 473. This contrasted with the small offering of only twenty-nine early music editions, including music theory, in Butsch's printed catalogue of $1844 \cdot{ }^{31}$ That Butsch directly approached the Hofbibliothek is not surprising, as earlier in 1845 Anton Schmid had published a ground-breaking book

25 Hans-Jörg Künast, 'Dokumentation: Augsburger Buchdrucker und Verleger', in Augsburger Buchdruck und Verlagswesen von den Anfängen bis zur Gegenwart, ed. Helmut Gier and Johannes Janota (Wiesbaden, 1997), 1205-1340 at 1312.

${ }^{26}$ Frieder Kocher-Benzing, 'Butsch, Fidelis', in Lexikon des gesamten Buchwesens Online, <https://dx.doi. org/10.1163/9789004337862_COM_022051> (consulted 30 September 2019).

27 For a list of known Butsch sales and auction catalogues, see Gerhard Loh, Bibliographie der Antiquariats-, Auktionsund Kunstkataloge, 8 (Leipzig, 1988), 91-99; and, for catalogues focusing on music, James Coover, Antiquarian Catalogues of Musical Interest (London, 1988), 32, No. 508, who lists only one Butsch catalogue, the Seltene Notendrucke of 1846 .

28 Wolfram Steude, ed., Die Musiksammelhandschriften des 16. und 17. Jahrhunderts in der Sächsischen Landesbibliothek $z u$ Dresden (Leipzig, 1974), 19-20, 23.

29 Hereafter A-Wn.

3o Österreichische Nationalbibliothek, Allg. Verwaltungs- u. Korrespondenzakten Hofbibliothek (1575-1920), Karton 19, $78 / 1845,6$. This item contains letters from Butsch to Anton Schmid dated 5 and 25 November 1845; and file duplicates of correspondence from Schmid to Butsch: a purchase request dated 5 December, and a letter dated 13 December (see $<$ https://data.onb.ac.at/rec/DZoooo4806>: 'Anbot von Musikalien'). Karton 20, 95/1845 consists of a letter from Butsch dated 18 December 1845 (see <http://data.onb.ac.at/rec/DZoooo4824>: 'Preisangabe für den Ankauf musikalische Werke' with the note: 'Im Protokollbuch handschriftlich vermerkt: wird in der Sitzung vom 10. Jänner zum Vortrag gebracht'); and Karton 21, 265/1846, consists of a letter from Butsch to Schmid dated 26 November 1846, and a file duplicate of Schmid's reply dated 10 December 1846 (see <http://data.onb.ac.at/rec/DZooo05129>: 'Anbot von Musikalien'). I am grateful to A-Wn for supplying me with scans of each of these letters.

${ }_{31}$ Nr. XIX. Catalog der Birett'schen Antiquariats-Buchhandlung F. Butsch in Augsburg, May 1844, 158-59. Exemplar at D-Mbs Cat. 116 q/19. 
on sixteenth-century music printing, focusing on Ottaviano dei Petrucci and his successors in the first half of the sixteenth century. ${ }^{32}$ In addition to descriptions of music editions, Schmid listed the collections that held them, including of course the holdings of the Hofbibliothek. Butsch therefore knew not only of Schmid's keen interest in early music editions, especially from the first half of the sixteenth century, but also the Hofbibliothek's holdings. ${ }^{33}$ Butsch therefore was able, in his letter, to single out twelve items that he thought would be of particular interest to Schmid, and sent them to the Hofbibliothek for inspection. Butsch followed up with another letter of 25 November, requesting confirmation of the safe arrival of the books sent with the first letter, and enclosing a treatise by Bermudo. ${ }^{34}$ Schmid replied on 13 December, enclosing a list, dated 5 December, of the books that he was most interested in acquiring; on that list, Schmid included seven of the items sent for inspection on 5 November, ${ }^{35}$ the Bermudo sent on 25 November, and a number of other items; these are all listed in Table 1.

Schmid stated that he could not place a firm order until Butsch had informed him of the prices of the books, and requested that in the future no books should be offered or sent without prices. ${ }^{36}$ Butsch responded on 18 December with the prices of the books; the prices that appear in a column in the left-hand margin of the file copy of Schmid's letter of 5 December therefore must have been added after the receipt of Butsch's letter. Butsch communicated the prices in two lists, the first for the items that he had sent to the Hofbibliothek for inspection, and the second for the items that Schmid had requested without inspection, which were still in Augsburg. ${ }^{37}$ The third page of Butsch's letter of 18 December noted corrections to two items of interest to Schmid; there is no evidence how the errors arose. Schmid listed Othmayr's 'Tomi duo' (item 8 of his list), but Butsch responded that he had vol. 1 only. ${ }^{38}$ Schmid's book noted holdings of the Royal Library in Munich, and so he presumably had a catalogue of that library. ${ }^{39}$ If so, he could have discovered that it possessed only vol. 1 of Othmayr; neither Munich nor any other

32 Ottaviano dei Petrucci da Fossombrone, der erste Erfinder des Musiknotendruckes mit beweglichen Metalltypen, und seine Nachfolger im sechzehnten Jahrhunderte (Vienna, 1845).

33 In a preface dated March 1846, Butsch referred to Schmid's book as 'indispensible for friends of early music' ('den Freunden alter Musik unentbehrlichen Buche'); Fidelis Butsch, Catalog einer Sammlung seltener Notendrucke des XVI. und XVII. Jahrhunderts ... zu haben in der Birett'schen Antiquariats-Buchhandlung F. Butsch in Augsburg (Augsburg, 1846), 5 (exemplar of the Leipziger Stadtbibliothek - Musikbibliothek, Leipzig).

34 Karton 19, 78/1845, 2 and 4. This time Butsch included a price: 30 florins for the Bermudo.

35 The seven acquired items were numbers 1-5, 10, and 15 in Table 1. The five not purchased were: 44. Jardin Musiqual (one or more of Waelrant \& Laet, RISM [1555] ${ }^{22}$ and 155617-19); 373. [Fiorino] Canzonelle a 3 et 4 voci in lode d'alcune gentildonne genovesi (Gardano, 1574; RISM F 950); 418. Fünff u. sechzig teutscher Lieder [RISM [1536] ${ }^{8}$; 453. Chansons nouvelles (see n. 80 below); and 454. Recueil de chansons. 2 vols. Quer $4^{\circ}$ (see n. 23 and n. 24 above). Of these, three appeared in the 1846 catalogue with more detail, specifying that No. 373 (Catalog, 2, fourth-last entry) was complete, but that 453 (p. 23) and 454 (p. 29) were incomplete.

36 ‘...weil die Angaben der Preise fehlen, noch keiner ämtlichen Verhandlung unterzogen werden können.... Schließlich bitte ich, Bücher ohne Angabe der Preise uns in Zukunft weder zu offeriren, noch zu übersenden.' Karton 19, 78/1845, 10. I am grateful to Hilary Howes at The Australian National University for the transcription of Schmid's handwriting.

37 Karton 20, 95/1845, four pages.

${ }_{38}$ Butsch's exemplar of the Symbola was in an original leather sixteenth-century binding together with the Novum et insigne opus musicum (RISM 1537') and the Secundus tomus novi operis musici (RISM 15383), both held by the Hofbibliothek (Schmid, Ottaviano dei Petrucci, 181-82). Presumably Butsch's catalogue was unclear that the Othmayr was part of a convolute containing a number of titles, but this was resolved in the printed version of the catalogue, Seltene Notendrucke (1846), 8, where No. 330 was clearly listed as consisting of the three titles.

39 Catalogues of the music collection were accessible; for example, the Belgian musicologist François-Joseph Fétis (17841871) owned a manuscript copy of a catalogue of the Munich Hofbibliothek that had been prepared by Johann Baptist Bernhart (preface dated 29 July 1795); this manuscript, 'Catalogus librorum musicorum tum manuscriptorum tum impressorum in electorali bibliotheca Bavarica Monacensi asservatorum' is now in the Royal Library of Belgium, Brussels, with the shelfmark Fétis 5179. Schmid wrote that he did not include any editions by Montanus and Neuber, 

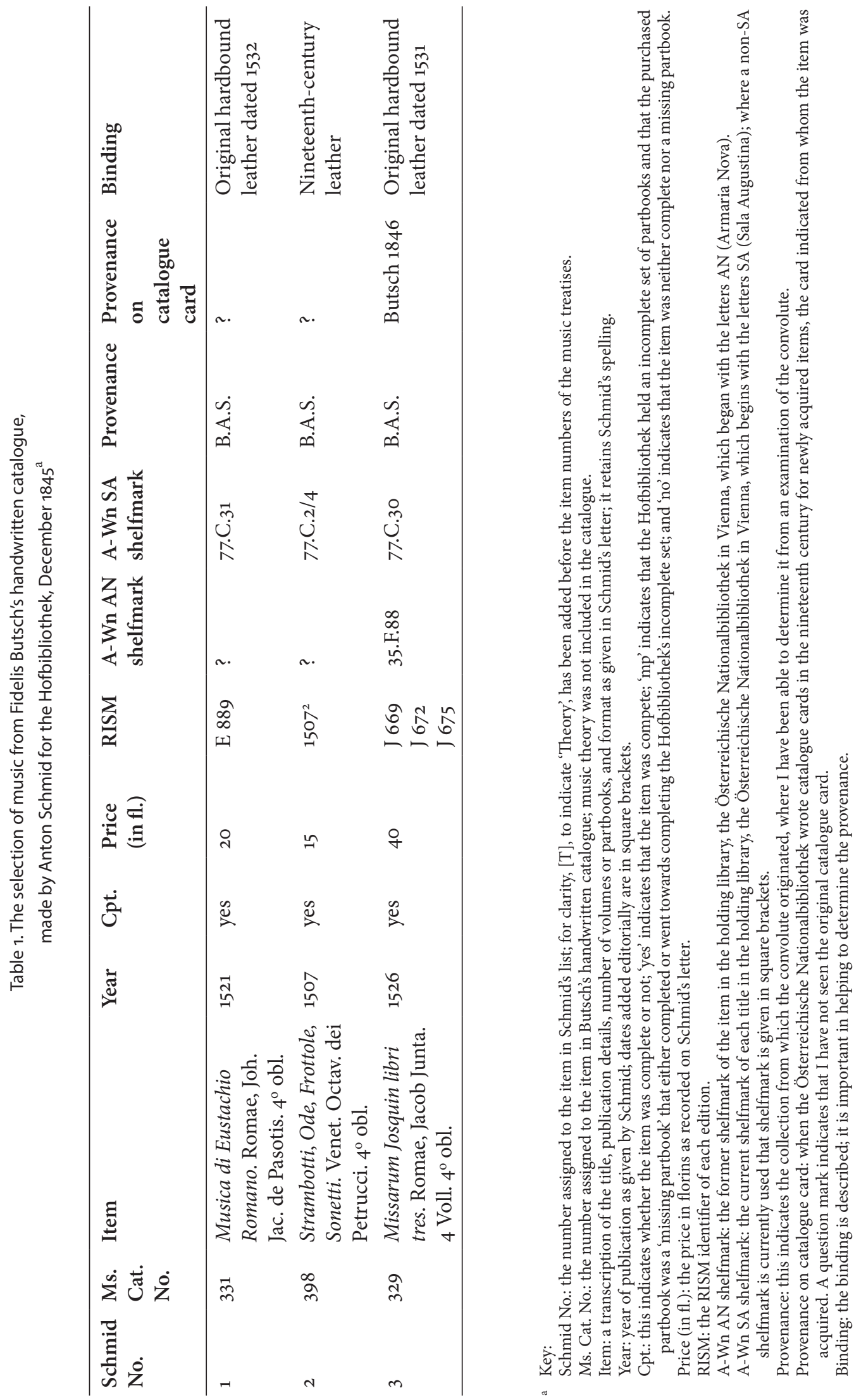


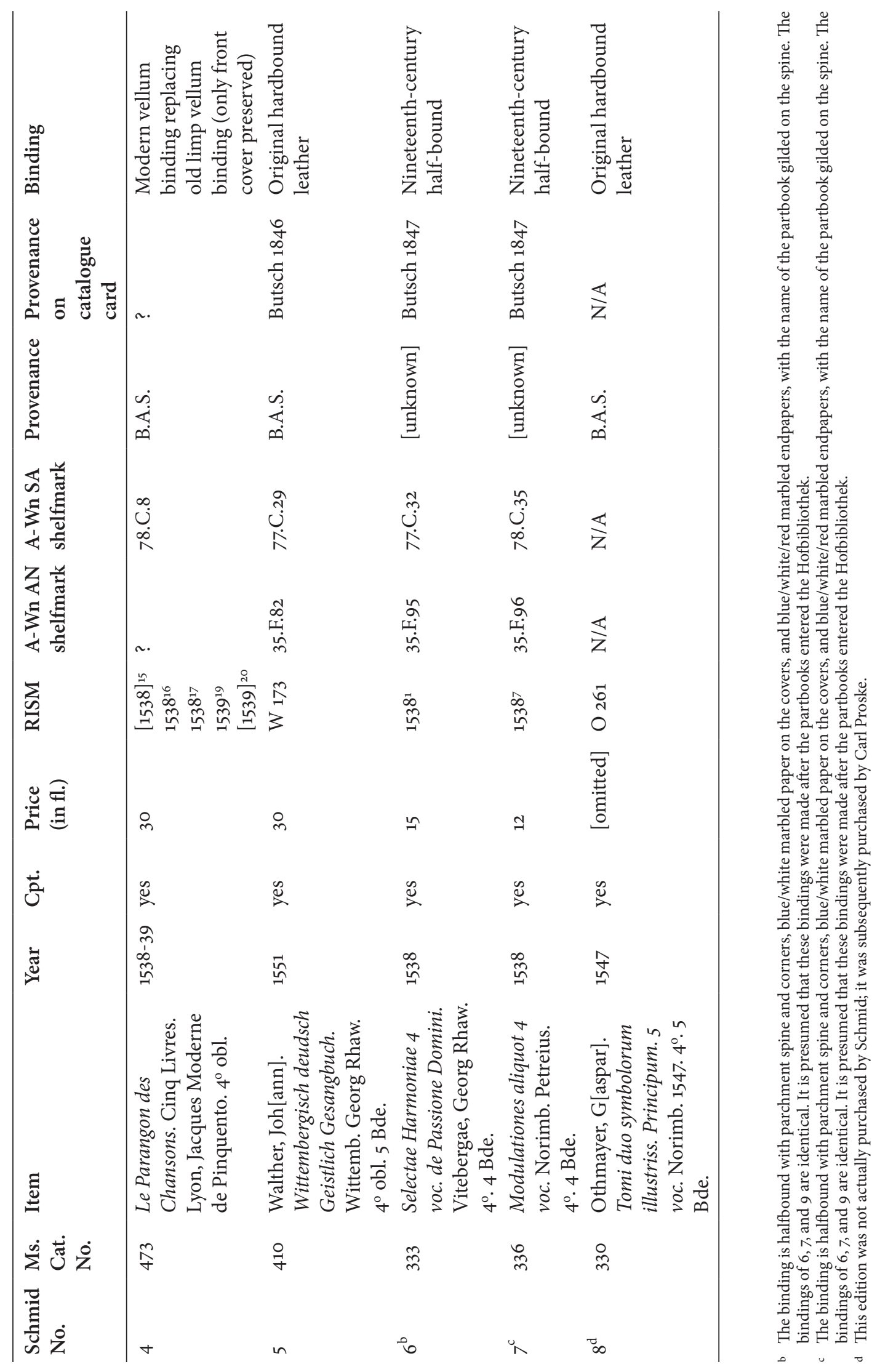




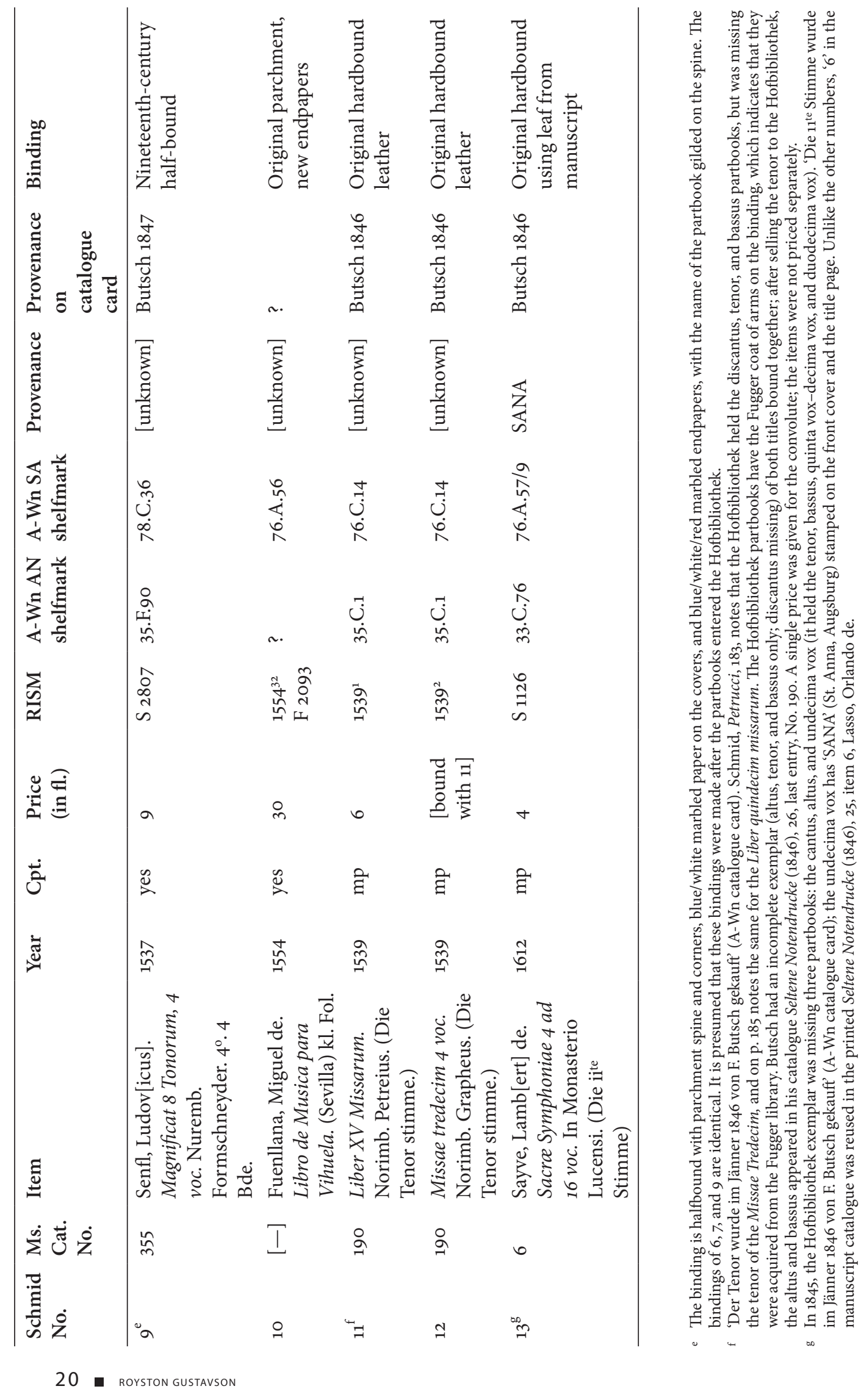




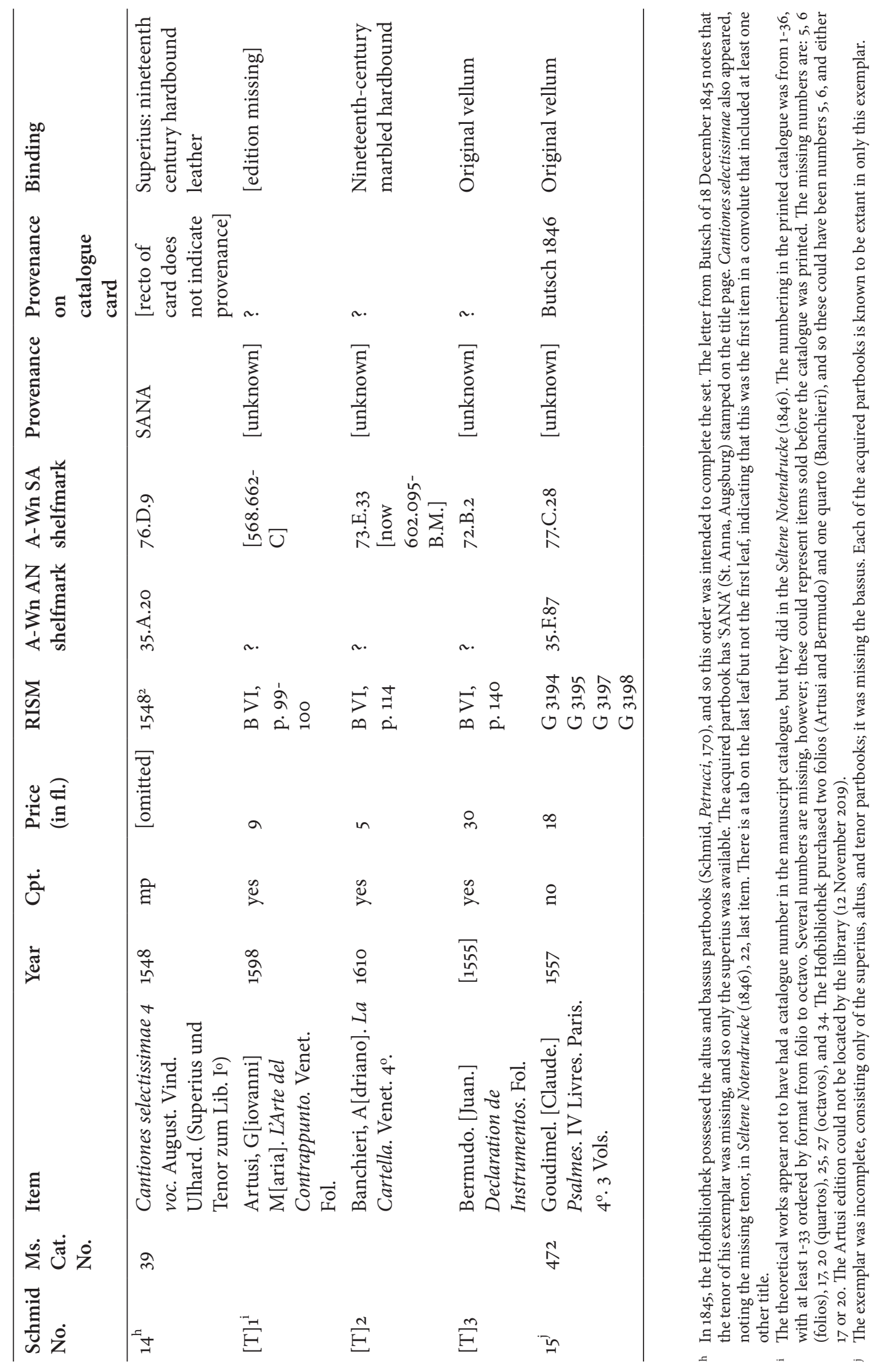


libraries known to Schmid possessed vol. 2, which was unknown and therefore attractive.$^{40}$ Schmid did not proceed with the acquisition of vol. 1; it subsequently appeared in Butsch's public sale list, Catalog einer Sammlung seltener Notendrucke des XVI. und XVII. Jahrhunderts, und einer Anzahl neuerer Musikwerke, zu haben in der Birett'schen Antiquariats-Buchhandlung F. Butsch in Augsburg (henceforth Seltene Notendrucke), and was purchased by Carl Proske (see below). Item 14 on Schmid's list was the superius and tenor partbooks of the Cantiones selectissimae, ${ }^{41}$ but Butsch responded that he did not have the tenor of vol. 1, only the superius; nevertheless, Schmid apparently acquired the superius. ${ }^{42}$

Schmid's book on Petrucci lets us draw conclusions about why he chose the items that he did. The first item on his list was the Musica di Eustachio Romano; Schmid wrote in his book that the first polyphonic editions printed in Italy after Petrucci were printed in 1526 in Rome, ${ }^{43}$ and so this edition was important in moving that date five years earlier, to 1521. The second item on his list is Petrucci's fourth book of frottole. Butsch singled out this volume in his letter of 5 November, listing it as ' 398 . Strambotti, ode, frottole, libro 4.' Butsch underlined the volume number as he knew, from Schmid's book, that the Hofbibliothek held books 1, 2, 3, 5, 6, and 9 of this series. ${ }^{44}$ The Hofbibliothek acquired book 4 and gave it the same full leather binding that it gave all of its Petrucci editions; although there are thus no B.A.S. shelfmarks in the Vienna exemplar of this book, other evidence ties this exemplar to Salzburg, as given in the description of selected convolutes below. The third item is the 1526 Dorico reprint of Petrucci's three volumes of Josquin masses; although Schmid's book includes the Dorico reprint of Petrucci's Motetti della Corona ${ }^{45}$ it doesn't mention the reprint of the masses; these were thus previously unknown editions from the earliest days of music printing. The fourth item, vols. 1-5 of Moderne's Parangon des chansons, is listed as being in Munich, ${ }^{46}$ and so these were previously known editions; however, up to that point, all the Moderne editions in the Hofbibliothek contained sacred music, and so this was an opportunity to add some secular music to the Hofbibliothek's holdings. Finally, although the Walther songbook is somewhat later than the other items, it was still a rarity: in his book, Schmid mentioned the $1524,1525,1537$, and 1544 editions, ${ }^{47}$ but not that from 1551 .

Of the twelve non-B.A.S. exemplars in which Schmid expressed interest, seven were complete (see Table 1). Of the other five, all but one comprised single partbooks that completed, or went towards completing, sets of partbooks held by the Hofbibliothek.

as their editions did not fall within the incunable period of music printing, and they were still available in most German libraries (Schmid, Ottaviano dei Petrucci, 193).

40 Othmayr's Symbola states on its title page that it is volume 1; there is no evidence that volume 2 was ever published.

${ }_{41}$ Cantiones selectissimae quatuor vocum (Augsburg: Philipp Ulhart the Elder, 1548), RISM $1548^{2}$.

${ }_{42}$ I have assumed that the superius partbook now in A-Wn, which is in a different binding to the other partbooks in this set and, unlike the other partbooks, has the provenance 'SANA' stamped on the title page (see below at n. 49), is the superius partbook referred to in the correspondence, as the original Hofbibliothek catalogue card unusually does not indicate the provenance. A further caution is that the exemplar of this edition included in the Seltene Notendrucke is listed as consisting of the superius, altus, and bassus partbooks, but if the superius had been sold to the Hofbibliothek then the entry should have stated that the exemplar now consisted only of the altus and bassus partbooks. No price for this partbook is given anywhere in the correspondence, and so if acquired it must have been a one-off acquisition at a later date.

43 Schmid, Ottaviano dei Petrucci, 113.

44 Schmid, Ottaviano dei Petrucci, 28-29.

45 Schmid, Ottaviano dei Petrucci, 115.

${ }_{46}$ Schmid, Ottaviano dei Petrucci, 254.

47 Schmid, Ottaviano dei Petrucci, 194. 
Item 11-12 is a single convolute that binds together the tenor partbooks of the Liber quindecim missarum and the Missae tredecim. The Hofbibliothek's exemplars of these editions, which were also bound together, were missing the tenor partbook, and so this purchase completed the library's holdings of these editions. ${ }^{48}$ Items 13 and 14 also went towards completing sets of partbooks; of particular interest is that both have 'SANA' stamped in black on the title page, and item 13 also has 'SANA' stamped in black on the front cover of its original binding. This stamp indicates a provenance of St. Anna, Augsburg. ${ }^{49}$ The only other incomplete item ordered was the Goudimel Psalmes. ${ }^{50}$ In Schmid's letter to Butsch, this title was entered after the works of music theory; its description is split over two lines to the left of Schmid's signature and date, which indicates that it was added as an afterthought. Schmid's preference for complete sets is evident not only from what he purchased of the music sent by Butsch to Vienna for inspection, but also from what he did not purchase: four of the five titles he rejected were incomplete. ${ }^{51}$ The Hofbibliothek purchased further items from Butsch in 1846,1847 , and $1853 .{ }^{52}$

\section{Butsch's Next Sales}

Of the five items listed in Butsch's letter to Schmid that were not purchased by the Hofbibliothek, three appeared in Butsch's catalogue Seltene Notendrucke, but two did

48 Schmid, Ottaviano dei Petrucci, 183 and 185 . This tenor partbook is catalogued under the same shelfmark as the discantus, altus, and bassus partbooks already held by the Hofbibliothek, at SA.76.C.14. Butsch apparently had an incomplete set of these two editions, bound together, which was missing the discantus partbook. He sold the tenor to the Hofbibliothek, and in his 1846 catalogue, Seltene Notendrucke, 26, last entry, advertised the altus and bassus. The partbooks already held by the Hofbibliothek came from the Fugger collection, as indicated by the Fugger coat of arms on the binding of each; these bindings match those of the incomplete set of the Novum et insigne opus musicum (RISM 1537', missing bassus), purchased by Carl Proske from Butsch (now in D-Rp); it was originally catalogued B 234-236 but was re-catalogued as A.R. 58. (The incomplete exemplar of the Novum et insigne opus musicum catalogued at A.R. 58-61 is missing the discantus, and so combining these two incomplete sets creates one 'complete' set). The Hofbibliothek was not permitted to sell its duplicates but could trade them (Paisey, 'Adolphus Asher', 152); as it held a complete exemplar of the Novum et insigne opus musicum (SA.76.C.3), its incomplete exemplar would have been traded with Butsch as a duplicate.

49 Although these do not appear in his Seltene Notendrucke, Butsch sold four other partbooks from the St. Anna set of Sayve partbooks (numbered 5, 7, 9, and 10) to Carl Proske; they are now catalogued at D-Rp B 185-192. For the St. Anna provenance of the Regensburg partbooks, see Jane A. Bernstein, 'Buyers and Collectors of Music Publications: Two Sixteenth-Century Music Libraries Recovered', in Music in Renaissance Cities and Courts: Studies in Honor of Lewis Lockwood, ed. Jessie Ann Owens and Anthony M. Cummings (Warren MI, 1997), 21-33 at 33; Bernstein was not aware of any 'SANA' editions still in Vienna. The identification of the 'SANA' monogram as belonging to St. Anna, Augsburg, was made in Haberkamp and Reutter, Thematischer Katalog II, xxiv. Extensive work on the St. Anna collection has been undertaken by Richard Charteris; see, for example, 'A Neglected Anthology of Sacred Vocal Music Dating from the Sixteenth Century', Music \& Letters 90 (2009), 1-34, and further publications listed at 11, n. 28.

50 Claude Goudimel, Premier livre de psalmes de David (Paris: Le Roy \& Ballard, 1557), Second livre de psalmes de David (Paris: Le Roy \& Ballard, 1559), Tiers livre contenant huit pseaumes de David (Paris: Le Roy \& Ballard, 1561), Quart livre contenant huit pseaumes de David (Paris: Le Roy \& Ballard, 1560).

${ }_{51}$ This is also clear in a later offer from Butsch to Schmid; on 10 December 1846, Schmid replied that he had selected few items from the catalogue as so many sets were incomplete, and the incomplete sets had so few of their partbooks ('In dem, der k. k. Hofbibliothek mitgetheilten Verzeichnisse alter Musikdrucke gibt es einerseits so wenig vollständige Werke, und andererseits aus den unvollständigen so wenig Stimmbücher, daß unser[e] Wahl auch nur gering ausfallen kann.), Karton 21, 265/1846, 3 . I am grateful to Hilary Howes, at The Australian National University, for the transcription of Schmid's handwriting.

52 The 1847 purchase of five items is detailed in the letter HB 265/1846 of 10 December 1846 from Schmid to Butsch; none of these items appeared in the 1846 Seltene Notendrucke and so had presumably been recently acquired. The 1853 purchase, as indicated from the library's catalogue cards, included SA.78.F.28/1-4: Motetti libro primo and quarto (Venice: Antico, 1521; RISM 15213 and 15215); SA.76.F.52: Opus decem missarum (Wittenberg: Rhaw, 1541; RISM 15411); SA.78.B.34: Tritonius, Harmoniae (Augsburg: Öglin, 1507; RISM T 1250); and the manuscript Mus.Hs.16703-GF. 
not: the Fünff $u$. Sechzig teutscher Lieder and the Jardin musiqual. ${ }^{53}$ This implies that Butsch had approached another purchaser and sold those items prior to the publication of his catalogue. As such, it must be considered whether or not these exemplars may have a B.A.S. provenance. Butsch's letter gave no information other than the titles but, as he had singled out these items for the Hofbibliothek, it is reasonable to assume that each set consisted of more than a single partbook. Schmid's focus on the first half of the sixteenth century suggests that if the Lieder (c. 1536) was complete, he would have purchased it. Of all currently known exemplars of the Lieder, the only possible match for the Butsch exemplar is that which was in the former Royal Library in Berlin (now the Staatsbibliothek zu Berlin-Preußischer Kulturbesitz, Musikabteilung, hereafter D-B). ${ }^{54}$ The surviving exemplars of the Jardin musiqual have been described in detail by Robert Lee Weaver. ${ }^{55}$ The British Library exemplars can be ruled out. ${ }^{56}$ The most likely match is with the first two books of four-voice chansons acquired by the Royal Library

53 There are two editions of the Fünff und Sechzig teutscher Lieder: the first was printed in Strasbourg by Peter Schöffer the Younger some time between 1533 and 1536, and the second was a reprint in Frankfurt am Main by Christian Egenolff in 1552; both are given as RISM [1536 $]^{8}$. Four different editions with the title Jardin musiqual were printed in Antwerp by Waelrant and Laet: one volume of three-voice chansons in C. 1555 (RISM [1555] 22), and three volumes of four-voice chansons in 1556 (RISM 155617-19). The second and third book of four-voice chansons spell the title Jardin musical, suggesting that neither of these was the first item in Butsch's convolute. Schmid's book, Ottaviano dei Petrucci, 272-73, gives a detailed description of the edition of three-voice chansons, but does not mention any of the editions of fourvoice chansons. It must be pointed out that Schmid does not actually mention the holding library of the three-voice chansons, but his description of the edition is so detailed that he surely had an exemplar in front of him when writing the entry, and throughout the book this is only the case for editions held in Vienna, something that Butsch could surely have inferred. As noted above, Butsch tended to single out items that were not known to Schmid, which favours the entry referring to at least the first book of four-voice chansons. In any case, two of the four known exemplars of the three-voice chansons can be ruled out. The exemplar in the Royal Library of Belgium (Cl. 11.991 L.P.) was purchased in 1840 and so cannot be the Butsch exemplar; see the Catalogue des accroissements de la Bibliothèque Royale ...

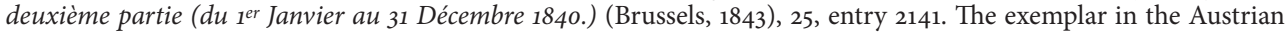
National Library (SA.76.D.22), in addition to presumably being Schmid's source, has a hand-written catalogue card that makes no reference to Butsch but has the date 1841 .

54 I have examined first-hand all partbooks of each edition except for the bassus partbook of the first edition in D-FRu; as a single partbook, it can be ruled out as the Butsch exemplar. Of the first edition, the complete sets in D-Mbs and $\mathrm{D}-\mathrm{Z}$ were in those collections by the seventeenth century. The British Library exemplar with the shelfmark K.8.i.9 is a single partbook with an acquisition date stamp of ' $18 \mathrm{JU}$ 94'. That leaves only the exemplar formerly in the Royal Library in Berlin and now in the Jagiellonian Library in Cracow with the shelfmark Mus. ant. pract. S 665. This is a composite set, with the discantus, altus, and bassus partbooks coming from one set and the tenor coming from another set. Elisabeth Giselbrecht has studied this exemplar in detail in 'Manuscript and Print Combined: Re-discovered Manuscript Additions in the Kraków Copy of Peter Schöffer's Third Songbook (1536)', in 'Teutsche Liedlein' des 16. Jahrhunderts, ed. Achim Aurnhammer and Susanne Rode-Breymann (Wiesbaden, 2018), 117-36 and at 119, n. 9 states that the tenor was acquired in 1868, but does not comment on the purchase of the other partbooks. The Staatsbibliothek zu Berlin has kindly informed me that it has no record of the purchase of the other partbooks (I am grateful to Jean Christophe Gero, wissenschaftl. Angestellter, Musikabteilung mit Mendelssohn-Archiv, Staatsbibliothek zu Berlin, for this information; email dated 3 February 2020). The evidence suggests that the discantus, altus, and bassus partbooks were acquired before 1868 , which is consistent with an 1846 purchase. That three partbooks were present means that the set was complete enough for Butsch to single it out for Schmid. Of the Egenolff reprint, the partbooks in Munich were purchased in the sixteenth century (see Richard Charteris, Johann Georg von Werdenstein [1542-1608]: A Major Collector of Early Music Prints [Sterling Heights MI, 2006], 178), and the single partbook acquired by the Royal Library in Berlin (now PL-Kj Mus. ant. pract. G 305) is the third of four titles in the convolute and so can be confidently ruled out.

55 Robert Lee Weaver, A Descriptive Bibliographical Catalogue of the Music Printed by Hubert Waelrant and Jan de Laet, Detroit Studies in Music Bibliography 73 (Sterling Heights MI, 1994), 21-22, 44, 60, and 78, gives a detailed description of each exemplar, including its binding. The partbooks in Cracow only became known after the publication of his book, but are described in a supplementary pamphlet, Additions and Corrections to A Descriptive Bibliographical Catalogue of the Music Printed by Hubert Waelrant and Jan de Laet (Sterling Heights MI, 1998), 6-9; he notes that the exemplars of the Jardin musiqual purchased by the Royal Library in Berlin are all in nineteenth-century marbled bindings.

56 Weaver does not examine purchase details. The exemplar of the altus, tenor, and bassus partbooks of the three volumes of four-voice chansons, RISM 155617-19, in the British Library (A.431), appear on the Asher \& Co. invoice of 19 July 1862, 14, item 331: 'Waelrant. Tenor. Jardin Musical \&c. 9 [pts]', but as the Jardin musiqual is not in the Seltene Notendrucke, it was presumably sold by Butsch prior to March 1846. 
in Berlin, now in the Jagiellonian Library in Cracow (Mus. ant. pract. W 30). ${ }^{57}$ That the same library may have purchased both the Lieder and the Jardin musiqual is not unexpected, as Butsch had only had a few weeks between finalizing the Vienna sale and the publication of Seltene Notendrucke. Butsch may have offered yet other music to the library in Berlin, but as any editions purchased at this time would not have appeared in Butsch's later catalogue, I have not been able to identify what they may have been..$^{58}$ In any case, I have not to date identified any B.A.S. exemplars among the music formerly in the Royal Library in Berlin.

\section{The Published Butsch Catalogue of 1846}

In 1846, Fidelis Butsch published his forty-two-page sale catalogue, Seltene Notendrucke. The preface was dated March 1846, and an advertisement for the catalogue appeared in the March 25 issue of the Allgemeine musikalische Zeitung. ${ }^{59}$ Butsch, as in all of his catalogues, included only a very short entry for each item: ${ }^{60}$ here he gave the author, title, publication details, the catalogue number in brackets, and the price; for incomplete editions, he also specified the partbooks present. ${ }^{61}$ The catalogue was arranged in sections, commencing with complete rare editions in upright quarto, then oblong quarto, then octavo (one item only); incomplete rare editions with the same subdivisions; complete and then incomplete editions in all other formats $\left(2^{\circ}, 12^{\circ}, 16^{\circ}\right)$; music theory; and finally two pages of recent editions. Within each section, the editions are organized by author or, in the case of anthologies, editor or title.

Combining the numbering in the catalogue with the numbering of the volumes purchased by Vienna, Table 2 shows that of the identified B.A.S. volumes held by Butsch, the oblong quartos in Latin are clustered (328-31), as are the French-texted and octavo editions; the sole edition of instrumental music, the Muffat Armonico tributo, has a very different catalogue number to the vocal music. ${ }^{62}$

57 The Staatsbibliothek zu Berlin has kindly informed me that it has no record of the purchase of any of these partbooks. I am grateful to Jean Christophe Gero, wissenschaftl. Angestellter, Musikabteilung mit Mendelssohn-Archiv, Staatsbibliothek zu Berlin, for this information (email dated 3 February 2020). The Berlin library also at some time acquired a complete exemplar of the three-voice chansons (now PL-Kj Mus. ant. pract. W 28).

58 This material could have included rarities already held by the library in Vienna and so not included in Butsch's selection for Vienna.

59 A. Nagel, 'Ankündigungen: Neue Musikalien bei Butsch in Augsburg', Allgemeine musikalische Zeitung 48/12 (25 March 1846), col. 215. Exemplars of the catalogue exist in the Bibliothèque royale de Belgique, Brussels (Fétis 5207), Leipziger Stadtbibliothek - Musikbibliothek, Leipzig (Musik-Bibliothek Peters, P 2762), Bayerische Staatsbibliothek, Munich (Mus. Th. 3902), Bibliothèque nationale de France, Paris (Z-6 (2)), Universitätsbibliothek der Eberhard-KarlsUniversität, Tübingen (De 57) and Library of Congress, Washington (ML 152.B48).

6o Erich Carlsohn, 'Fidelis Butsch \& Sohn: Die Antiquare von Augsburg', in Börsenblatt für den Deutschen Buchhandel, Frankfurter Ausgabe, 15/104 (30 December 1959), 1938-40 at 1939, who also notes that the reputation of the firm for detailed descriptions and bibliographical references began under Butsch's son, Albert Fidelis Butsch.

${ }_{61}$ For three of more than 500 items he included information from Schmid's book, Ottaviano dei Petrucci.

${ }_{62}$ No. 327 (p. 8) is a complete exemplar of the three-volume Psalmorum selectorum printed by Petreius (RISM $1538^{6}$, $1539^{9}$, and $1542^{6}$ ); of the known complete exemplars, those in Vienna and Jena were listed as being in those libraries in 1845 in Schmid (p. 187); Regensburg, Bischöfliche Zentralbibliothek, Proske Musiksammlung (hereafter D-Rp) A.R. 74-76 is of a Regensburg provenance; and the description of the binding of the exemplar in PL-Kj in the $v d m$ does not suggest a B.A.S. provenance. No. 332 (p. 7) is the Lamentationes Jeremiae printed by Montanus \& Neuber (RISM 15491), which was purchased by Carl Proske and is now at D-Rp B 36-38, but that exemplar has no binding; where there are end-papers, they are blank. No. 333, not in Seltene Notendrucke, was acquired by the Hofbibliothek; it has a nineteenth-century binding and end-papers, and so there is no evidence of B.A.S. provenance. 
Table 2. Identified B.A.S. music editions in the Butsch catalogue, Seltene Notendrucke

\begin{tabular}{lll}
\hline Catalogue No. & Catalogue page/A-Wn & Catalogue item \\
\hline 328 & 6 & Isaac, Choralis Constantinus \\
329 & A-Wn & Josquin, Missae \\
330 & 8 & Ott, Novum et insigne opus musicum \\
331 & A-Wn & Eustachio Romano, Musica \\
398 & 6 (vols 2-3); & Petrucci, Frottole \\
& A-Wn (vol. 4) & \\
410 & A-Wn & Walther, Wittembergisch deudsch Geistlich \\
454 & 29 & Gesangbüchlein \\
455 & 38 & Recueil de chansons anciennes \\
465 & 38 & Selectissimorum triciniorum \\
473 & A-Wn & Selectissimae necnon familiarissimae cantiones \\
3812 & 36 & Le Parangon des chansons \\
\hline
\end{tabular}

\section{Acquisitions by Carl Proske (now in the Bischöfliche Zentralbibliothek, Regensburg)}

Carl Proske (1794-1861), a collector and editor of early music, purchased many titles from Butsch's Seltene Notendrucke, almost exclusively editions of sacred music. The purchased items have been identified by Haberkamp and Reutter, who demonstrated that the 'Butsch' shelfmarks B 1-167 in Proske's library exactly follow the order of the entries in Butsch's Seltene Notendrucke, and that B 45-50 and B 163 came from the B.A.S. ${ }^{63}$ To their findings can now be added the discoveries that B 170-172 was purchased from Seltene Notendrucke, that B 33-35, which consists of Petrucci's second and third books of frottole, also came from the B.A.S., and that there is a B.A.S. shelfmark on the spine of B 241 (in addition to the shelfmark on the front cover that Haberkamp and Reutter already identified). ${ }^{64}$ It is clear from an examination of Seltene Notendrucke that Proske selected editions that did not duplicate complete items in his extensive collection of music collected from Regensburg institutions, catalogued as 'Antiquitates Ratisbonenses' (shelfmarks A.R.). He entered his Butsch purchases into his 'Catalogus Butsch' (manuscript without shelfmark), a onevolume handwritten catalogue of printed editions and manuscripts to which he gave a shelfmark beginning ${ }^{\mathrm{B}} \mathrm{B} .{ }^{65}$ It is likely that Butsch made his purchases soon after the catalogue was issued, as they include many of the rarest items, including two of the only three sets of partbooks for which the catalogue refers the reader to Schmid's book for a discussion

\footnotetext{
${ }_{63}$ Haberkamp and Reutter, Thematicher Katalog II, xxii-xxvi, and xxvii, n. 101. The two editions are indicated only by shelfmark with no further details, not even the titles of the editions, but as this is a catalogue of manuscripts this should not be surprising.

${ }_{64}$ B 170-172 appears on p. 37 of Seltene Notendrucke, five entries after what is now B 167. B 33-35 appears on p. 6 of Seltene Notendrucke; by error, it has no item number, which may have been caused by the inclusion of additional text about these two Petrucci editions.

65 For example, D-Rp B 45-50 and its contents are catalogued on 45-51.
} 
of their rarity and importance. ${ }^{66}$ It should be noted that after his initial purchases, Proske made further purchases from the catalogue; for example, an edition by Zeuner was later purchased and catalogued as $\mathrm{C}$ 39-42 (C denoting 'Continuatio zur Abteilung Butsch'). ${ }^{67}$

In addition to the printed editions from Seltene Notendrucke, Proske's purchases from Butsch, all included in his 'Catalogus Butsch', include five manuscripts and a printed edition with a manuscript appendix that had come from the B.A.S. collection. ${ }^{68}$ No B.A.S. manuscripts have been identified in any Butsch catalogues. ${ }^{69}$ The correspondence between Proske and Butsch was destroyed after Proske's death, and so no further details of these purchases are known. ${ }^{70}$

It should be noted that Proske's shelfmarks do not indicate the number of partbooks, but the number of repertorial layers. For example, the Missae tredecim at B 44 has only one shelfmark even though it consists of four partbooks. On the other hand, B 259-267 consists of a single manuscript partbook. Therefore, the shelfmarks of the Stomius partbooks do not indicate the number of partbooks in each set, but the number of repertorial layers identified by Proske. This explains why Reg II (B 216-219) consists of three partbooks and Reg III (B 220-222) consists of four partbooks. ${ }^{71}$

\section{Acquisitions by Otto Kade (now in the Sächsische Landesbibliothek, Dresden)}

The music scholar Otto Kade (1819-1900) acquired two partbooks from Seltene Notendrucke that were from the B.A.S. No. 455 comprised two partbooks each binding together four editions of tricinia, three of which are now in the British Library; they are in an original binding and are certainly from the B.A.S. The B.A.S. inscription on the front free end-paper of the British Library convolute reads 'Triciniorum select: Discantus [Bassus] || cum Chatechesi Musicali || Sㅍ38'. The Seltene Notendrucke states that Mattheus Le Maistre's Catechesis numeris musicis inclusa is the final item in the convolute. ${ }^{72}$ The inscription on the title page and the description by Butsch are brought together by the title page of the discantus, which reads 'Primus discantus In Catechismo Musicis numeris ornato, à Matthaeo le Meistre. This implies that at some time between 1846 and 1861, the Le Maistre became separated from the convolute. If the Le Maistre but not the tricinia

66 A set of six partbooks containing all five volumes of Gardano's Thesaurus musicus for 80 florins (pp. 4-5), now at D-Rp B 14-29; Petrucci's second and third books of frottole for 36 florins (p. 6) now at D-Rp B 33-35; and a set of four partbooks containing all three volumes of Petreius' Psalmi selecti for 33 florins (p. 8), however as Proske already held this set of partbooks (D-Rp A.R. 74-76), he did not purchase it, but it may be the exemplar acquired by the Royal Library in Berlin and now at PL-Kj Mus. ant. pract. P 645.

${ }_{67}$ The $\mathrm{C}$ shelfmarks commence with further editions purchased from Butsch (Haberkamp and Reutter, Thematischer Katalog II, xxvi-xxxi); we know that the Zeuner is the same exemplar as that in Seltene Notendrucke, 5 (No. 411), as both are described as having an appended manuscript of sixty German lieder.

${ }_{68}$ Haberkamp and Reutter, Thematischer Katalog II, xxv, lists these six items.

69 I have examined Butsch catalogues including all of those in D-As and GB-Lbl.

7o August Scharnagl, 'Geschichte der Proskeschen Musiksammlung', in Haberkamp, Thematischer Katalog I, xi-xxvi, at xxii and xxvi.

${ }_{71}$ In the B.A.S. partbooks at D-Rp B 45-50, the distribution of the shelfmarks among the repertorial layers is indicated in neither the partbooks themselves nor in Proske’s 'Catalogus Butsch', where they are indexed on pp. 45-51. The distribution is presumably as follows: B 45, Novum opus musicum I, six-voice motets (as the sexta vox is in a separate partbook); B 46, Novum opus musicum I, five-voice motets (as the quinta vox is in a separate partbook); B 47, Novum opus musicum I, four-voice motets; B 48, Novum opus musicum II, six-and five-voice motets (as the quinta and sexta voces are in the same partbook on facing pages); B 49, Novum opus musicum II, four-voice motets; B 50, Othmayr, Symbola.

72 Seltene Notendrucke, 38, item 455. 
was ordered by a customer, Butsch may have removed it from the convolute and sold it separately. There are only two known exemplars of the 1563 Le Maistre: a complete exemplar in Munich, and two of the three partbooks in the Sächsische Landesbibliothek in Dresden. The British Library partbooks measure 85 millimetres $\times 126$ millimetres; as they are in oblong octavo, they must have been heavily trimmed in the process of binding them in or after 1563. The Sächsische Landesbibliothek has kindly informed me that their Discantus primus book measures $84 \times 129$ millimetres and their Pars infima (bassus) measures $84 \times 127$ millimetres. Allowing for rounding errors and the use of two different rulers, the similarity of size clearly indicates that the British Library and Sächsische Landesbibliothek partbooks could have been previously bound together. Although the end-paper of each of the British Library partbooks has a free leaf at the beginning, neither has a free leaf at the end. Based on his examination of many editions sold by Butsch, Richard Charteris has kindly informed me that 'there are precedents for the retention of original bindings after major changes have been made to bound sets', and that the 'binding is looser at each end' of the British Library convolute, which provides the final evidence that the partbooks now in Dresden were previously part of the convolute now in London. ${ }^{73}$ The title page of the Dresden Pars infima has the word 'Kade' written on it in pencil, which suggests that the books derived from Kade's estate. ${ }^{74}$ Kade states in his 1862 book on Le Maistre that he had exemplars of the Discantus primus and Pars infima in his possession..$^{75}$ As the British Library purchase was in 1861 , and the Seltene Notendrucke was published in 1846 , these partbooks were available for purchase during the period when Kade would have been collecting material for his book. Le Maistre had a long and distinguished association with Dresden; he served as Kapellmeister at the Saxon Court from 1554, and remained in Dresden until his death in $15777^{76} \mathrm{It}$ is therefore not surprising that, in 1937, the year following the death of Otto Kade's son, Reinhard, in Dresden, these two partbooks, formerly in the B.A.S., ended up in the Dresden library. ${ }^{77}$

\section{Acquisitions by Freiherr von und zu Aufseß (now in the Germanisches Nationalmuseum, Nuremberg)}

Hans Philipp Werner, Freiherr von und zu Aufseß (1801-72), founded the Germanisches Nationalmuseum in Nuremberg, and in 1852 his private library formed the foundation of the museum's library. His collection included the altus and bassus partbooks of the

73 Email of 18 April 2020. I am grateful to Emeritus Professor Charteris for reading a copy of the submitted version of this article and for responding with this information.

74 I am grateful to Rahel Rockstroh of the Sächsische Landesbibliothek - Staats- und Universitätsbibliothek Dresden (SLUB) for this information (email dated 15 November 2019) and for the measurements of the partbooks.

75 Otto Kade, Mattheus le Maistre, Niederländischer Tonsetzer und Churfürstlich Sächsischer Kapellmeister [...]: Ein Beitrag zur Musikgeschichte des 16. Jahrhunderts (Mainz, 1862), 113.

${ }^{6}$ See Donald Gresch, Mattheus Le Maistre: Catechesis and Gesenge, Recent Researches in the Music of the Renaissance 39 (Madison WI, 1982), vii.

77 I am again grateful Rahel Rockstroh for the following information (email dated 14 November 2019). The partbooks have the shelfmark Mus.983-E-1. The accession numbers in the two partbooks indicate that they were acquired in 1937, however they do not appear in the general accession register for 1937; music was presumably in a separate register that is no longer extant. The binding is not an early binding but appears to be from the early twentieth century. It is not known whether the partbooks were bound before or after entering the library. 
Selectissimae necnon familiarissimae cantiones (RISM 15407$), 7^{7}$ their spines are painted white but a majority of the paint has flaked off and so only fragments of the shelfmark on the spine remain. However, the front free endpaper contains the other shelfmark: 'Musicalium diversorum Altus S $\underline{3} 36$ ' and 'Musicalium diversorum Bassus S $3{ }^{3} 36.79$ partbooks appeared in Seltene Notendrucke (p. 38, No. 465) in a descriptive entry as Butsch had not identified the title, which was printed only in the tenor, but the entry has enough information to make our identification unambiguous: 'Musicalia diversorum', with compositions by composers including Josquin, Jachet, Verdelot, and Senfl, printed in Augsburg by Melchior Kriesstein, and consisting of the altus and bassus partbooks only.

\section{Acquisitions by Thomas Dobrée (now in the Musée Dobrée, Nantes)}

Seltene Notendrucke lists two convolutes that match items held by the Musée Dobrée in Nantes and that were presumably purchased by the bibliophile Thomas Dobrée (1810-95). No. 453 (p. 23) is a convolute of twelve different editions of chansons nouvelles, one by Attaingnant and eleven by $\mathrm{Du}$ Chemin. ${ }^{80}$ This description matches printed editions 367 and 368 of the library of the Musée Dobrée. ${ }^{81}$ These editions are bound together in what appears to be a sixteenth-century vellum binding, but there are no indications of a B.A.S. provenance. ${ }^{82}$ This convolute is evidence that Dobrée purchased from Seltene Notendrucke, which is important for the next item in that catalogue for which the evidence is not so clear.

No. 454 in the Seltene Notendrucke is the 'Recueil de chansons anciennes à quatre parties, 4 livres (1, 2, 4 u. 5) Paris, N. Duchemin, [1]551. Tenor und Contratenor. ${ }^{83}$ The B.A.S. held vols. $1-5$ of this edition; the superius partbook is still held in the University Library of Salzburg. As discussed earlier, the superius and tenor of vol. 3 were printed on facing pages in the same partbook, and the B.A.S. exemplar binds this superius/tenor partbook with the superius partbooks of the other volumes, and so the tenor partbook of the B.A.S. set only contains vols. 1, 2, 4, and 5; this matches the description of the exemplar offered by Butsch in the Seltene Notendrucke. ${ }^{84}$ While this explains the entry

78 I am grateful to Martina Pfahler, Germanisches Nationalmuseum, Nuremberg, for this information (email dated 14 November 2019).

79 I am grateful to Irene Brunner, Germanisches Nationalmuseum, Nuremberg, for photographs of the spines and front free endpapers, and a link to the page of the handwritten library catalogue (email dated 29 November 2019). The partbooks have the shelfmark [Post inc.] $8^{\circ}$ M. 371 [3] and [Post inc.] 8० M. 371 [4].

80 This item is one partbook containing the superius and tenor (on opposite pages) of Attaingnant's first volume of Chansons nouvelles, RISM $1553^{20}$, and vols. 1-11 of Du Chemin's Chansons nouvelles, RISM $1550^{7}$ (vol. 1), $1549^{25-27}$ (vols 2 , 3, and 4), 15509-12 (vols 5, 6, 7, and 8), $1551^{9}$ (vol. 9), $1552^{5}$ (vol. 10), and $1554^{21}$ (vol. 11).

${ }_{81}$ M.-Louis Polain, Catalogue de la Bibliothèque du Musée Thomas Dobrée, vol. 2 (Nantes, 1903), 216-17, Nos. 367-68.

82 I am grateful to Claire de Lalande, Conservateur du patrimoine, Chargée des collections modernes et contemporaines, des manuscrits, incunables et éditions rares, Grand Patrimoine de Loire-Atlantique (Musée Dobrée, sites patrimoniaux départementaux, pôle archéologique, laboratoire Arc'Antique), for this information (email dated 17 December 2019).

83 Seltene Notendrucke, 29.

${ }^{84}$ The only extant tenor partbook of each of vols. 1, 2, and 4 is now in the Staatsbibliothek zu Berlin, which also holds the tenor of vol. 5, suggesting that the B.A.S. tenor may be that purchased by the Royal Library in Berlin. These four tenor partbooks were in Berlin not later than 1877 as they are cited as the only known exemplars in Robert Eitner, Bibliographie der Musik-Sammelwerke des XVI. und XVII. Jahrhunderts (Berlin, 1877), 120-22. I am grateful to Jean Christophe Gero, wissenschaftl. Angestellter, Musikabteilung mit Mendelssohn-Archiv, Staatsbibliothek zu Berlin, for the following information (email dated 3 February 2020): the Staatsbibliothek has no records of the purchase of these partbooks, which have shelfmark Mus. ant. pract. D 522. From the photograph of the catalogue card and the binding sent by Mr Gero, the partbooks are bound together in a nineteenth-century half-binding of marbled paper over cardboard. 
in Seltene Notendrucke, the Musée Dobrée holds not the tenor but the contratenor, catalogued as No. 503. That convolute binds together the contratenor partbook of vols. 1, 2, 4, and 5, and the contratenor/bassus partbook of vol. 3; each of these five partbooks is known to exist only in this exemplar. How the tenor and contratenor became separated is not known. ${ }^{85}$ Like the set of superius partbooks remaining in Salzburg and the set of tenor partbooks in Berlin, this set of contratenor partbooks was also rebound in the nineteenth century, here in a half binding. ${ }^{86}$ This implies that the bindings of these partbooks had all deteriorated by the nineteenth century, which is further evidence of them being from the same set.

\section{Other Buyers between 1846 and 1861}

Editions listed in the Seltene Notendrucke appear in RISM and in the catalogues of many libraries, providing a basis for the search for further purchasers. Making possible identifications is particularly easy where Seltene Notendrucke lists multiple titles bound together if only one such convolute is known today, or where Butsch sold an incomplete set, and a particular library holds only those partbooks. ${ }^{87}$ In each instance, it is necessary to investigate the provenance of the exemplars held by those libraries, ${ }^{88}$ as for example in the above instances relating to Otto Kade. Once an item from the Butsch catalogue is identified, it must be examined for indications of a B.A.S. provenance; in many cases this remains to be done. The only other purchaser conclusively identified to date is the Hofbibliothek in Munich (now the Bayerische Staatsbibliothek, hereafter D-Mbs), which acquired item No. 32 (Seltene Notendrucke, 28), the Musica quatuor vocum (RISM 15499a), through exchange with Butsch on 1 May $1861 ;{ }^{89}$ however, this is not of B.A.S. provenance. A collection that I am yet to explore is that of François-Joseph Fétis, whose vast private music library is now in the Royal Library of Belgium..$^{90}$

85 As the Dobrée catalogue includes the contratenor partbook not under 'Musique' but under 'Belles lettres: Poesie Française', Dobrée may have collected this edition for its texts rather than for its music; as the texts are given in full in each partbook, only one partbook would be needed for this purpose. Nevertheless, this explanation must remain speculative.

${ }^{86} \mathrm{I}$ am grateful to Claire de Lalande for the information about the Dobrée bindings (email dated 17 December 2019).

87 This was also noted by Haberkamp and Reutter, Thematischer Katalog II, xxiii, who by comparing the incomplete sets of partbooks in listed in RISM with the incomplete sets of partbooks listed in Seltene Notendrucke suggest a number of libraries now holding material that had appeared in the catalogue; however, apart from the items in D-Rp, no confirmation of specific cases was undertaken.

88 This is not always straightforward. For example, Seltene Notendrucke, 5, No. 408, is a complete exemplar of the Bergkreyen (Nuremberg: Montanus \& Neuber, 1551), RISM 155120, of which there are complete exemplars in Heilbronn (which has been there since the sixteenth century), Munich, and Berlin. The exemplar now in Munich (D-Mbs $4^{\circ}$ Mus.pr. 454) was acquired by exchange with the Royal Library in Berlin on 29 October 1861 (I am grateful to Dr. Uta Schaumberg, Musikabteilung, Bayerische Staatsbibliothek, for this information), meaning that the Berlin library had two exemplars (the other is now PL-Kj Mus. ant. pract. R 755); one of the two Berlin exemplars may have been the Butsch exemplar.

89 I am grateful to Dr. Uta Schaumberg, Musikabteilung, Bayerische Staatsbibliothek, for this information (email dated 29 November 2019). Bernstein, Buyers and Collectors, 31, notes that this edition has a St. Anna, Augsburg, provenance; although mentioning Butsch, she does not refer to the Seltene Notendrucke. The Butsch set, like that in Munich, is missing the tenor; the only other known partbooks from this edition are a complete set in the Museo internazionale e biblioteca della musica di Bologna, Bologna.

90 As noted in fn. 59 above, the extant exemplars of Seltene Notendrucke include one in the Fétis collection; see Catalogue de la bibliothèque de F. J. Fétis acquise par l'État belge (Brussels, 1877), 608, No. 5207. Richard Charteris, 'Some Early Music Editions in Brussels and Regensburg: Their Historical Connections Unveiled', in In Monte Artium 1 (2008), 23-55 at 53, notes that in 1850 'Fétis visited Fidelis Butsch's establishment and there purchased 54 complete, sixteenthand seventeenth-century music editions and collections...? 


\section{Acquisitions by the British Museum (now the British Library)}

On 18 July 1861, the Trustees of the British Museum agreed to purchase 806 items of music from Adolf Asher and Co. in Berlin, though with Asher's agreement the Museum deferred the transaction for a year. ${ }^{91}$ The music arrived on 19 July 1862 ; the 'Invoice of Three Cases of Books, containing Music B.L.' survives in the British Library archives. ${ }^{92}$ The numbering of the items on the invoice itself is not consecutive, which implies that the numbers were copied from a now-lost Asher and Co. catalogue. ${ }^{93}$ Each of the books purchased via the invoice was date-stamped by the British Museum ' 19 JY 62' in red (red indicating purchases). The invoice includes at least two items from the B.A.S.: numbers 29 (p. 2, 'Isaac. Hein. Primus Tomus / tenor / 4 [parts]') and 515 (p. 22, 'Selectissimorum Triciniorum Discantus \&c 2 [parts]').

These two B.A.S. items had previously been listed in the 1846 Seltene Notendrucke. ${ }^{94}$ Indeed, many of the items purchased from Asher and Co. had also appeared in the Butsch catalogue; that they were the same books is evidenced by the many incomplete sets of partbooks for which the individual partbooks listed in the Butsch catalogue map exactly onto the partbooks purchased from Asher and Co. and that are now held by the British Library. David Paisey, in his study on Asher, noted that he had 'agents and "correspondents" in almost every European country'-Fidelis Butsch in Augsburg was one of his three agents in Germany ${ }^{95}$ - and that Asher 'continually took the initiative in seeking out and offering large numbers of works he considered the Museum should have. ${ }^{96}$ Asher sold his business in 1852 to Albert Cohn, who continued to operate it as Asher and Co. ${ }^{97}$ The evidence implies that Asher and Co. included music from the 1846 Butsch Seltene Notendrucke in its own catalogue, which is lost but presumably dated 1860 or 1861 , and sourced that music directly from Butsch. As such, there may be other items from the B.A.S. in the British Library from this Asher and Co. sale, but it was not feasible within the time constraints of this project to examine the large number of items that appear both in the Seltene Notendrucke and on this invoice.

${ }_{91}$ Alec Hyatt King, Printed Music in the British Museum: An Account of the Collections, the Catalogues, and their Formation, up to 1920 (London, 1979), 87. My count of the number of items includes each item number even when combined as one entry (for example, $460 / 61$ is counted as two items), and the seven unnumbered items.

92 GB-Lbl DH5/16, Department of Printed Books: Acquisition invoices, 10 June $1862-6$ October 1862. The invoice in question is a forty-two-page invoice from the Berlin bookseller A. Asher and Co. The invoice has an accession date of 19 July 1862, and is the only invoice for this date. I am grateful to the British Library Corporate Archives for this information (email dated 26 July 2018), and for supplying me with a complete scan of the invoice.

93 For a list of A. Asher \& Co. catalogues, see Gerhard Loh, Bibliographie der Antiquariats-, Auktions- und Kunstkataloge, 10 (Leipzig, 1990), 7-10; in addition, Dr. Loh has kindly informed me (email dated 12 March 2020) of Asher's Catalogue de livres rares provenant des bibliothèques de feu son Exc. Le Baron de W. et de quelques autres amateurs (Berlin, 186061), auction of part 1 (2879 numbers) commencing 30 October 186o, and auction of part 2 (2255 numbers) commencing 15 February 1861; I have not received detailed information from the holding libraries as at the time of writing. For Asher catalogues focused on music, see Coover, Antiquarian Catalogues, 5, numbers 66-68.

94 Page 6: 'Henrici Isaaci tom. I. II. et III. coralis Constantini [...] 4 Voll. Norimb. Hier. Formschneider, 550. (328) fl. 25'; and p. 38: 'Selectissimorum Triciniorum tomi III. discantus et bassus. Norib., Joh. Montanus et U. Neuber, 559. (enth. deutsche, latein., franz. u. italin. Lieder.) - b.) Math. le Meistre, catechesis numeris musicis inclusa, et ad pueror. captum accommodata, 3 voc. ibid. 563 (Tenor und Bassus.) (455) fl. 3.30 kr.' Note that Butsch abbreviated the year of publication by omitting the first numeral, ' 1 '.

95 David Paisey, 'Adolphus Asher (1800-1853): Berlin Bookseller, Anglophile, and Friend to Panizzi', in The British Library Journal 23 (1997), 131-53 at 136. See also Friedhilde Krause, 'The Royal Library, Berlin, and its Contacts with Great Britain in the Nineteenth Century', in The Library, Sixth Series, 7 (1985), 211-17 at 215.

96 Paisey, 'Adolphus Asher', 132.

$97<$ https://www.asherbooks.com> (accessed 25 January 2019). 
I suggest that all the early editions in the Seltene Notendrucke that were not purchased by 1861 and that did not duplicate items already held by the British Museum were purchased by the British Museum by way of Asher and Co. ${ }^{98}$ The amount of material not purchased is indicated by the missing item numbers on the invoice; for example, of items numbered 1-100, the museum did not purchase 3-7, 22, 26, 35, 39, 44, 65, 87b-c, and 93. Nevertheless, assuming that the B.A.S. exemplars passed through Seltene Notendrucke, it remains possible to search for material sold after the British Museum purchase. ${ }^{99}$

\section{Reconstructing the B.A.S. Music Collection}

Before proceeding, I should clarify the use of terminology relating to the paper added to a volume by the binder during the binding process, as the literature does not use this terminology consistently. I have used the term 'end-paper' to identify a bifolium, that is, a piece of paper folded in half to create two conjugate leaves, of which one leaf 'is pasted down on the inner cover of the binding' (the 'paste-down'), and the other leaf is not pasted down but is like the leaf of a book (the 'free end-paper'). Blank leaves added by the binder that are not an endpaper are referred to as 'binders' leaves. ${ }^{100}$

As no catalogues of the B.A.S. music collection survive, its holdings can only be reconstructed from surviving volumes. The B.A.S. volumes are identifiable by one or both of the following characteristics. Firstly, their spines were almost invariably painted with a yellow-grey oil paint; an exception is a set of volumes bound in cream vellum, now at D-Rp B 163. On the spine of the binding of these volumes is a handwritten shelfmark in the format ' $\mathrm{S}_{\overline{3}}$. [number]. B.A.S'. In some instances, presumably following the dispersal of the collection, the paint and with it the shelfmark has been removed, but fragments remain that indicate that they were once painted. Secondly, there is a very brief handwritten description and a shelfmark in the format ' $\mathrm{3}$ [number]'; for example, 'Eustachij Musica liber $\mathrm{i}$ mus. $\mathrm{S} \underline{\mathbf{3}} 16 .{ }^{101}$ For volumes bound in plain cream vellum this is written on the front of the binding. In volumes bound in leather or in coloured vellum, this catalogue number and description is typically written on the free leaf of the endpaper. Where this leaf is missing, it is found on the title page; where it has been used for copying music, the catalogue number may be on the paste-down. Common to both series of shelfmarks is the prefix $\mathrm{S} \underline{3}$ or $\mathrm{S}_{\overline{3}}$, which presumably indicated the physical location of the shelving in which the music was housed. The key difference in the numbering systems is that the system of shelfmarks written on the spine gave a separate number to

${ }_{98}$ However, for six items the invoice has, in red pencil, 'R. Dupl' written over the item and the number of parts crossed out in red. This suggests that these items were already held by the library and had been ordered in error.

99 Asher \& Co's Extrait du catalogue LXVIII de livres rares et curieux ... musique (Berlin, [1862]) and catalogue 74, Catalogue d'une belle collection de musique ancienne (Berlin, 1863), both of which survive at D-Mbs Mus. Th. 3875 , may include unsold material from the lost catalogue from which the British Museum made its purchase; I will be examining this possibility in the next stage of my research on the B.A.S.

${ }^{100}$ I follow Fredson Bowers, Principles of Bibliographical Description (Princeton, 1949), 378, except that he uses the term 'lining-paper' where I use the term 'paste-down', to follow the term generally used in the musicological literature; see, for example, Stanley Boorman, 'Glossary', in Music Printing and Publishing, ed. Donald W. Krummel and Stanley Sadie (New York, 1990), 489-550 at 508 'End-paper' and 525 'Paste-down'.

${ }^{101}$ Other examples include '11: O Donij Cantica varia Discantus [Contratenor / Tenor / Bassus / 5- vox / vox 6 ${ }^{\text {ta }}$ ]'; and '17: Isaac. Dominico à Trinit. usq[ue] ad advent:. Discantus. Tomi 1. 2. et 3.' 


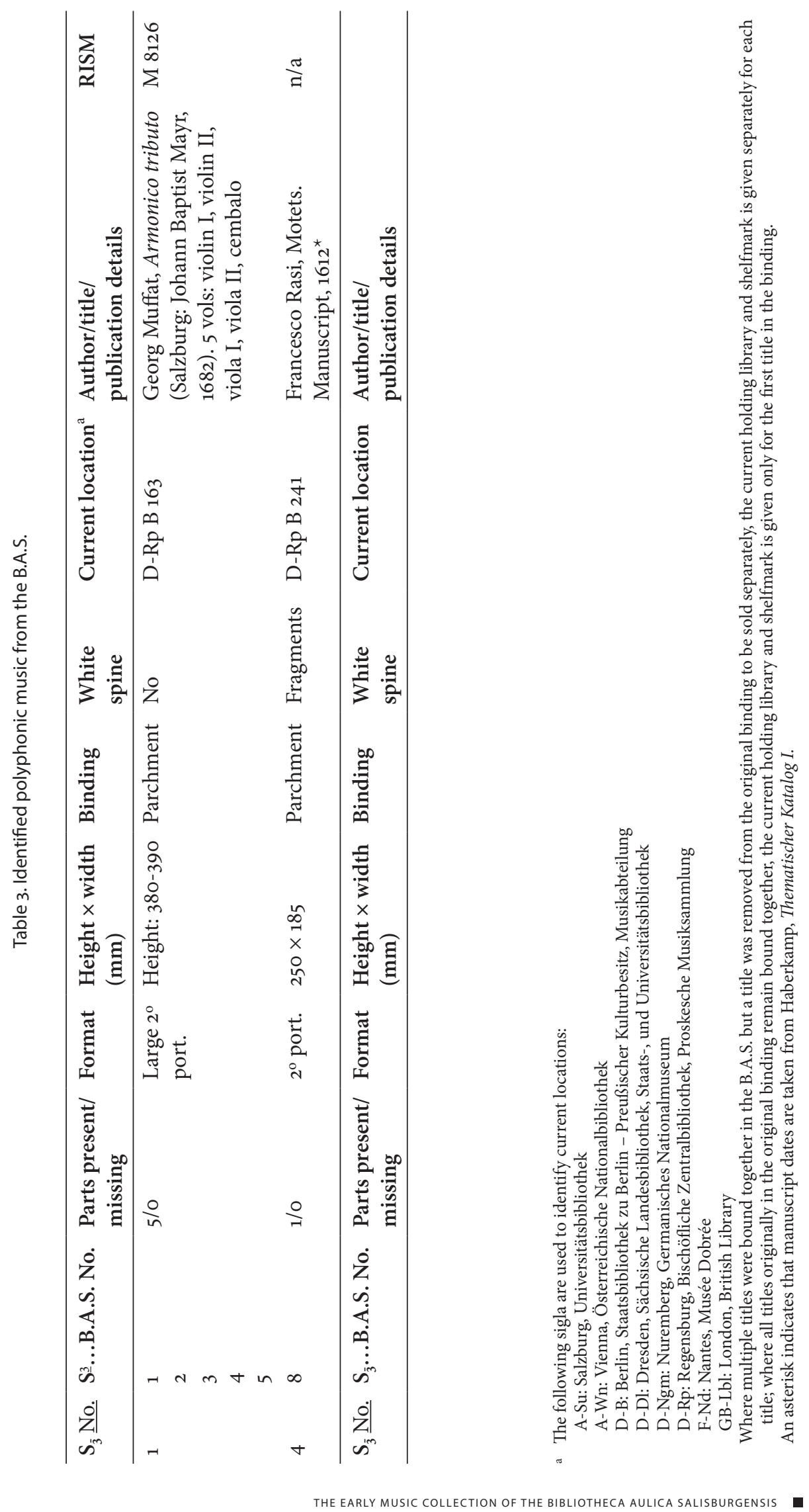




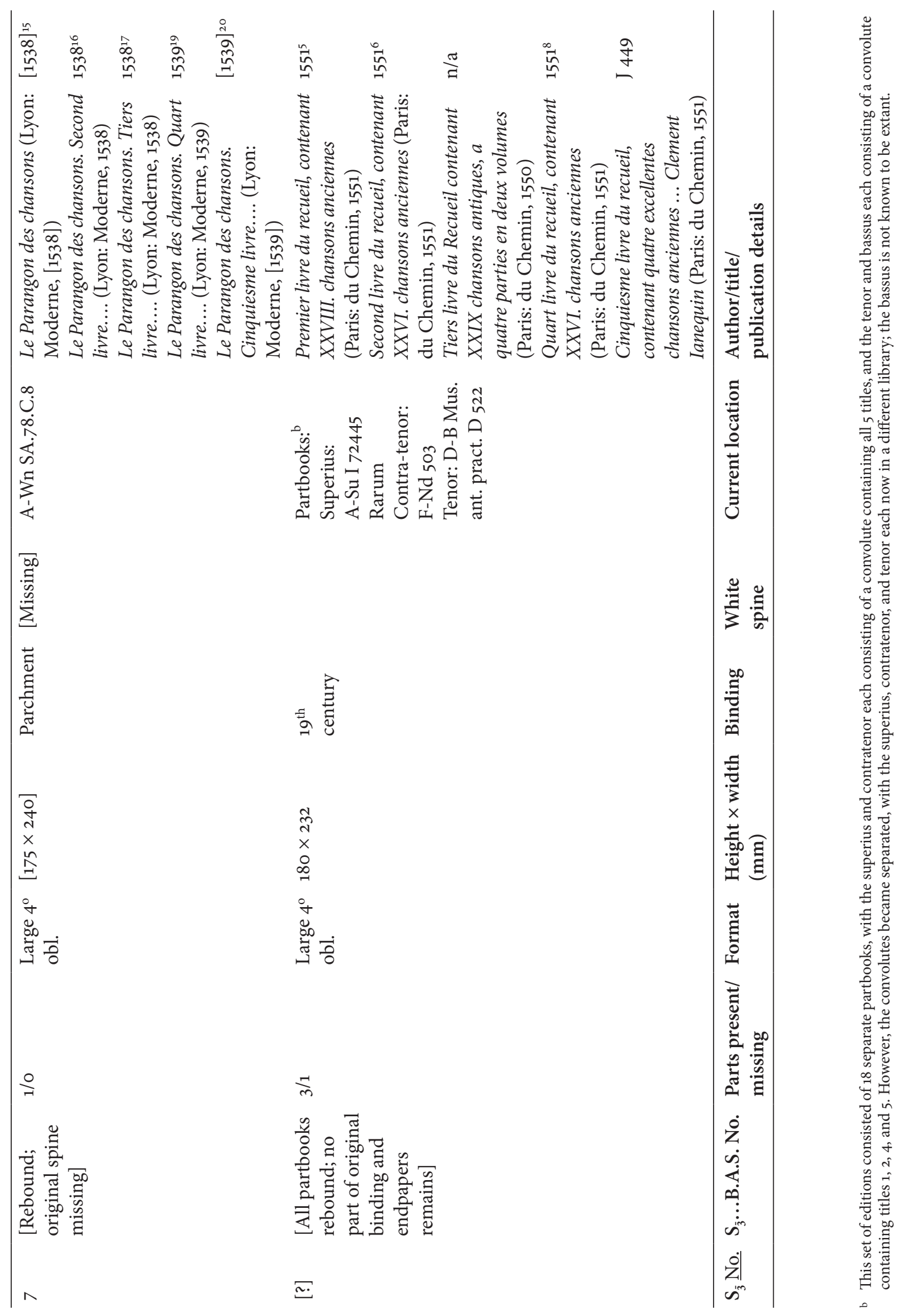




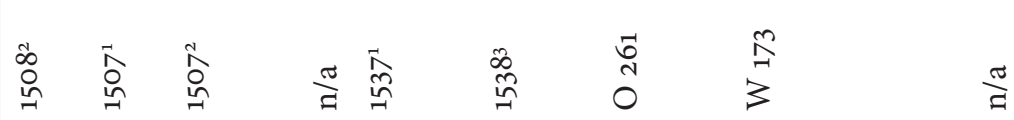

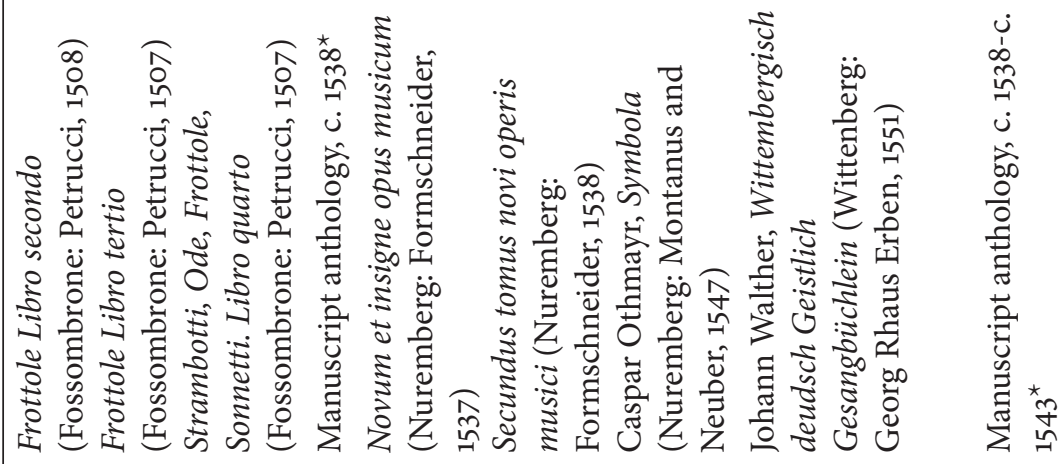

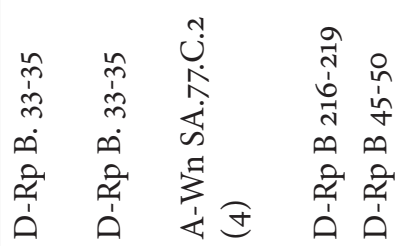
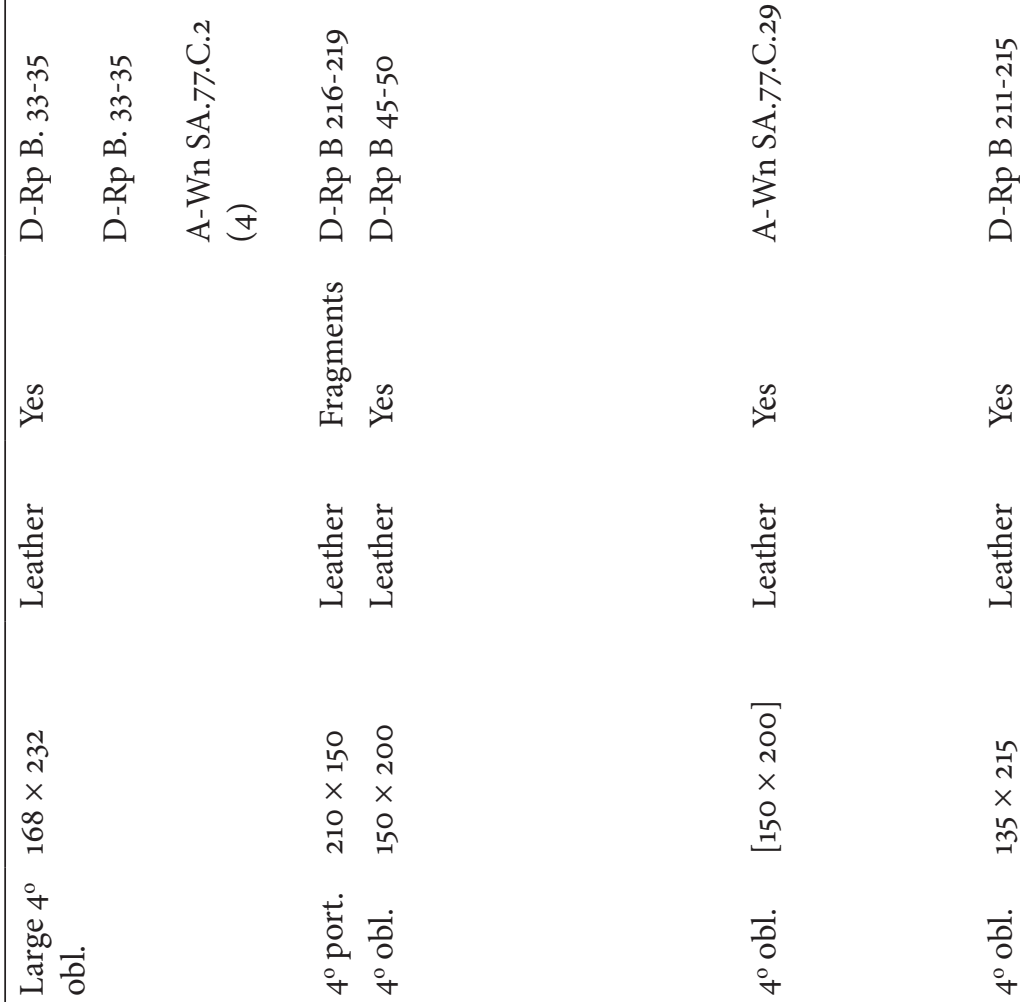

$\stackrel{\circ}{\frac{0}{m}} \frac{0}{6}$

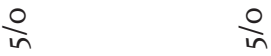

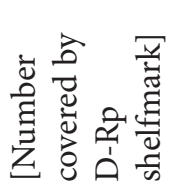

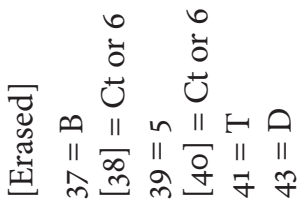

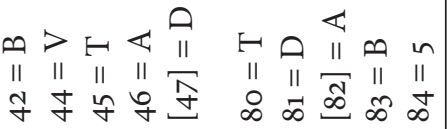

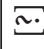

$\stackrel{ }{=}$

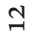

$\approx$ 


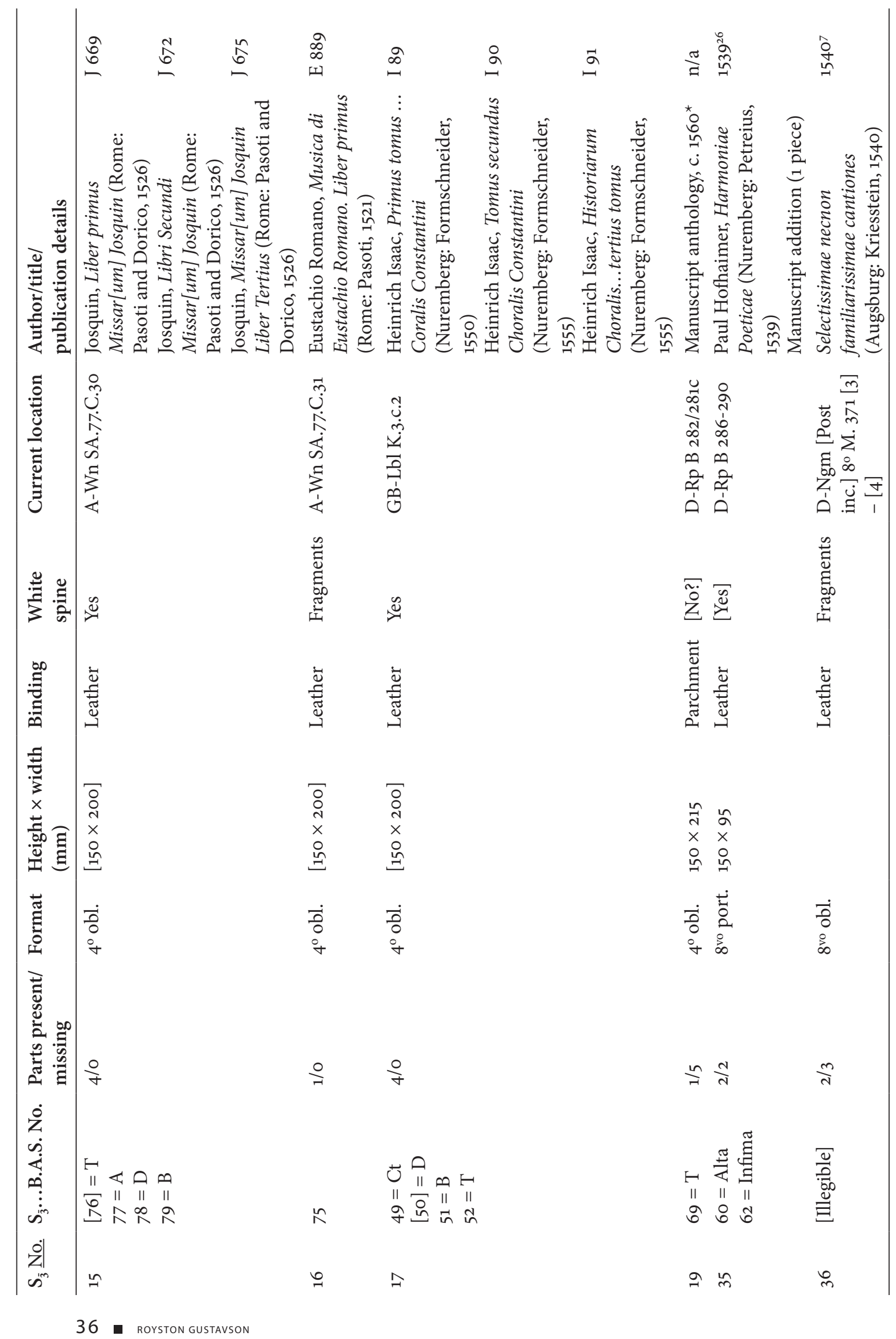




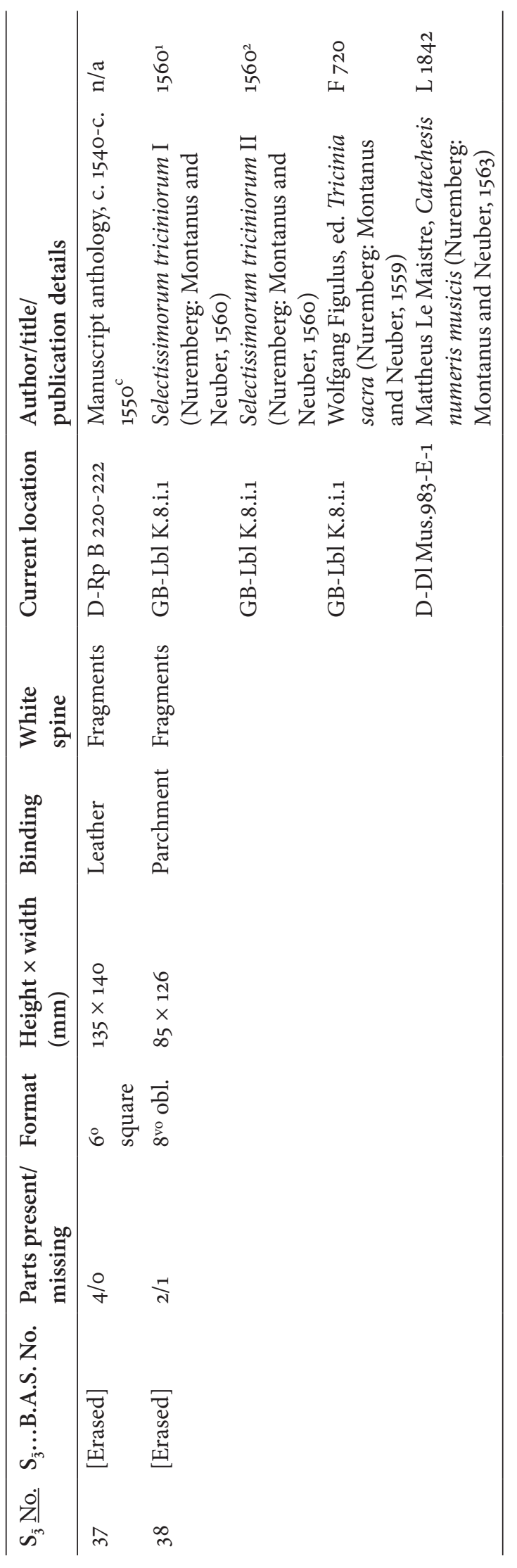

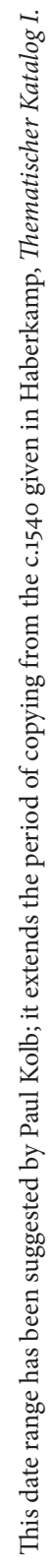


each individual partbook, while the system of shelfmarks on the front covers or endpapers gave one number to each set of partbooks. In either case, however, the identification of the B.A.S. provenance is normally dependent on the survival of the binding and/or front end-paper. In both series, the number ' 1 ' is assigned to Georg Muffat's Armonico tributo (1682), and so both series of shelfmarks must have been applied in 1682 or later.

Table 3 lists all identified music books from the B.A.S. It will be noted that more were identified from the shelfmark on the flyleaves or front covers than from the shelfmark on the spine, since the latter shelfmark has been erased on several bindings.

The first series of shelfmarks is on the spine of each volume. Of the sixty-two identifiable individual bound volumes, fifty are extant and twenty-eight have legible shelfmarks on the spines, ranging from number 1 to number 84 , but the sequence probably extended to at least $96 .^{102}$ This implies that just over half of the B.A.S. music collection has been identified to date. Seven additional shelfmarks can be inferred; for example, the four partbooks of the Choralis Constantinus have three numbers (49, 51, and 52); although the original spine of the other partbook is not extant, we can infer that it was number 50 . The known shelfmarks are also clustered, with a large gap between 9 and 29: 1-5, 8, [30-31 were music theory], 37-47, 49-52, [53 was music theory], 60-62 [and either 59 or 63], 69 [one of a sequence of six consecutive numbers], and 75-84. This sequence also tells us that $S_{\overline{3}} 48$ was a single volume. For the vocal partbooks, the voices are not numbered in any specific order, with the lowest number of each sequence being assigned indiscriminately to the altus, the tenor, and the bassus. It is curious to note that, with each partbook having a separate number, two sets have been intermingled, as indicated in Table 4.

Table 4. $S_{\overline{3}}$ numbering of the B.A.S. Novum opus musicum and Geistliche Gesangbüchlin

\begin{tabular}{lll}
\hline $\mathrm{S}_{\overline{3}}$ number & Title & Partbooks \\
\hline $37-41$ & Novum opus musicum & All except discantus \\
42 & Walther, Geistliche Gesangbüchlin & Bassus \\
43 & Novum opus musicum & Discantus \\
$44-47$ & Walther, Geistliche Gesangbüchlin & All except bassus \\
\hline
\end{tabular}

(In the second catalogue series, written here on the front end-papers, these two sets were numbered consecutively as $S^{\underline{3}} 11$ and $S^{3}$ 12). With so few shelfmarks present, no pattern relating to the numbering sequence on the spines can be discerned with confidence, except that the folio volumes have the lowest numbers $(1-5,8)$; all other volumes with this series of shelfmarks are of approximately the same height (oblong quarto or upright octavo), with the printed books having lower numbers than the manuscripts.

The second series of shelfmarks, marked on the front cover, front end-paper, or title page, numbers sets rather than parts. All but two of the seventeen identified sets have numbers ranging from $S \underline{3} 1$ to $S \underline{3} 38$; of the others, one has been rebound and the other is severely damaged. It is clear that this series was arranged according to the height of the books, regardless of whether they were printed or manuscript. The height, where known, is given here in brackets:

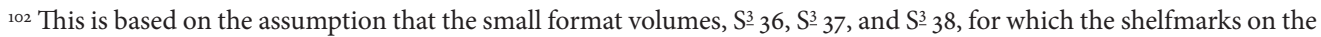
spine have been erased or are no longer legible, would have had shelfmarks following the quartos and upright octavos. 
Folio: $S^{3} 1$ ( $38-39$ centimetres high $), S^{3} 4(25 \times 18.5$ centimetres $)$

Quarto oblong (large): $\mathrm{S} \underline{3} 7(17.5 \times 24$ centimetres)

Quarto upright: $S^{3} 10(21 \times 15$ centimetres $)$

Quarto oblong: $S^{\underline{3}} 11(15 \times 21$ centimetres $), S^{\underline{3}} 12, S^{\underline{3}} 13, S^{\underline{3}} 15, S^{\underline{3}} 16, S^{\underline{3}} 17, S^{\underline{3}} 19$

Octavo upright: $\mathrm{S} \underline{3} 35(15 \times 9$ centimetres $)$

Sexto square: $\mathrm{S}^{3} \mathbf{3} 7(13.5 \times 14$ centimetres $)$

Octavo oblong: $S^{\underline{3}} 36$ (not measured), $S \underline{3} 38(8.5 \times 12.6$ centimetres; this exemplar has been heavily trimmed)

This suggests that the tallest volume was numbered $\mathrm{S} \underline{3} 1$; if this is the case, then the collection did not include the Liber selectarum cantionum (RISM 15204), which is 44.5 centimetres high. ${ }^{103}$ This is surprising given that the dedicatee of this publication was Matthaeus Lang, archbishop of Salzburg; it might have been expected that the B.A.S., which consolidated the collections of previous archbishops of Salzburg, would have included an exemplar of this edition.

As these shelfmarks do not appear on the spine, it would be very difficult to find individual items on a bookshelf. These shelfmarks must surely have also appeared on the spine, and were either later overpainted (for example, the word 'Novi' can be seen through the paint on the top of the spine of the discantus of $S \underline{3} 11$ ), or were perhaps written on pieces of paper pasted onto the spine, which have all now disappeared without trace-unless this series preceded the B.A.S. series of shelfmarks; as potential evidence of this, the flaking of the paint on the spine of the Petrucci volume has exposed part of a label that was painted over. Although the collection could have included more oblong octavos, only a very small amount of polyphonic music was printed in a format with a height smaller than standard oblong octavo: these exceptions include the square duodecimos of Peter Schöffer the Younger, and the oblong sextodecimos of Egenolff and Montanus and Neuber. As such, it is unlikely that the B.A.S. contained many more than thirty-eight sets. The fact that all seventeen sets identified to date were present in the Butsch Antiquariat in 1845 suggests that Butsch purchased the entire music collection from the B.A.S. It also suggests that fewer than half of the sets in the B.A.S. music collection have been identified to date. It was argued above that more than half of the individual volumes have been identified, which implies that several of the unidentified items consist of a single volume only.

Fourteen of the seventeen sets of manuscripts and printed music are dated prior to the death of Johannes Stomius in 1562. Presumably owing to the cost of binding, most of the printed editions are bound together in convolutes of between three and five titles. Grantley McDonald's article in the present issue of this Journal demonstrates that five of these include Stomius's hand (S포 10, 13, 16, 35, and 37), and a sixth may demonstrate his hand (the Petrucci). Circumstantial evidence to link the others to Stomius comes from Paul Kolb's study of concordances and copying (also in this issue), as Stomius' readings derive from them ( $S \underline{z} 11$, 15, and 16); the binding of some of the sets has the same tooling, and was thus likely to have been bound by the same binder as one or more of the sets identified by McDonald or Kolb, or has end-papers with watermarks that have an association with Salzburg between the 1530s and the 1550 os ( $\mathrm{s}^{3} 10,13,16,17$, and 35$)$. Of the others, $\mathrm{S}^{3} 12$ is the 1551 edition of Walther's songbook, which has a binding linked to Salzburg; $\mathrm{S}^{3} 19$ is a manuscript from c. 1560, bound

${ }_{103}$ This measurement is from the exemplar in the British Library at K.9.a.24. 
in vellum, which is certainly from Salzburg; but the Moderne chansons ( $\mathrm{S} \underline{\mathbf{3}} 7$ ), Du Chemin chansons (unknown), and Kriesstein Selectissimae necnon familiarissimae cantiones ( $\mathrm{S} \underline{\mathbf{3}} 36$ ) have no identified link to Salzburg other than their provenance.

Of the three convolutes dating from after Stomius's death in 1562, the most interesting is $\mathrm{S} \underline{\mathbf{3}} \mathbf{3}$. Three of the four titles in this convolute date from before his death, but one dates from 1563, and so the convolute cannot have been from his collection. On the back paste-down is a diplomatic copy of a table from Stomius' treatise Prima ad musicen instructio, which indicates a link with his circle. $S \underline{3} 1$, printed in Salzburg in 1682, was presumably presented to the then-archbishop as a gift. ${ }^{104} \mathrm{~S} \underline{3} 4$, an autograph manuscript of motets with a dedication signed 1612, was likewise presumably presented to Markus Sittikus von Hohenems, archbishop of Salzburg (1612-19); the highly decorated gilded binding bears his gilded coat of arms. ${ }^{105}$

\section{Bibliographical Observations on the Music Editions up to 1563}

All but one of the printed music editions, the exeption being Muffat's Armonico tributo (1682), date from not later than 1563. Eleven of the B.A.S. music items from Stomius's lifetime or circle are sets of printed music. Seven of them are convolute volumes containing multiple editions, and so thirty different editions are represented in the collection. These are summarized in Table 5.

Table 5. Place and date of publication of editions in the B.A.S. to 1563

\begin{tabular}{llll}
\hline City & Publisher & No. of Editions & Date Range \\
\hline Augsburg & Kriesstein & 1 & 1540 \\
Fossombrone & Petrucci & 3 & $1507-8$ \\
Lyon & Moderne & 5 & $1538-39$ \\
Nuremberg & Formschneider & 5 & $1537-55$ \\
Nuremberg & Montanus and Neuber & 5 & $1547-63$ \\
Nuremberg & Petreius & 1 & 1539 \\
Paris & Du Chemin & 5 & $1550-51$ \\
Rome & Pasoti & 1 & 1521 [binding stamped 1532] \\
Rome & Pasoti and Dorico & 3 & 1526 [binding stamped 1531] \\
Wittenberg & Georg Rhaus Erben & 1 & 1551 \\
\hline
\end{tabular}

\footnotetext{
104 This is an edition of Georg Muffat's Armonico tributo (Salzburg, 1682). Ernst Hintermaier, 'Notenwidmungsdrucke und -handschriften Salzburger Provenienz vom 16. bis 18. Jahrhundert', in Auf eigenem Terrain: Beiträge zur Salzburger Musikgeschichte. Festschrift Gerhard Walterskirchen zum 65. Geburtstag, ed. Andrea Lindmayr-Brandl and Thomas Hochradner (Salzburg, 2004), 87-149 at 129-30, notes that the composer was in the employ of the Salzburg archbishop, Max Gandolph Graf Kuenburg. Hintermaier discusses the provenance of the exemplar now in the Bibliothèque nationale in Paris (from the collection of Sébastien de Brossard), but does not discuss the exemplar now in Regensburg. The Regensburg exemplar (D-Rp B 163; Seltene Notendrucke, 36) is of of particular interest. The front free end-paper has the word 'Correct.' in brown ink, and indeed some pages have ink corrections. The person who made these corrections has not yet been identified, but clearly the first hand to check is that of Muffat himself.

${ }^{105}$ See Hintermaier, 'Notenwidmungsdrucke', 108; and Haberkamp, Thematischer Katalog I, 228-29. I am grateful to Dr. Dittrich for a colour photograph of the binding.
} 
Nine of the printed editions contain sacred music: Latin mass ordinaries (three), Latin mass propers (three), Latin motets (two), German Kirchenlieder (one). Some of the secular music is suitable for use in a school and is consistent with what Stomius copied: editions of tricinia (four), bicinia (one), ode-settings edited by Stomius (one), and a collection of motets, each dedicated (by Othmayr) to a famous contemporary. Perhaps most surprising in an Archdiocesan library is the large number of editions of secular vernacular music: French chansons (10), Italian frottole (3), and a mixedlanguage anthology (1). As Grantley McDonald has discussed physical attributes of $\mathbf{3} \underline{3}$ $15, S=16$, and $S \underline{3} 35$, in the current issue of this Journal, I shall comment briefly on each of the others, except where I have discussed them at length above:

$S^{2} 7$ B.A.S. binds together five volumes of chansons. The original limp cream vellum binding has been replaced with a modern binding, but the front cover of the original has been bound in; it is our sole source of information relating to provenance. The $S 37$ shelfmark and the description 'Le Paragon [sic] de Chansons.' was written on the front cover.

S 11 B.A.S. binds together Hans Ott's two-volume Novum et insigne opus musicum (153738) and Othmayr's Symbola (1547), and so was bound not before $1547 .^{106}$ The other B.A.S. shelfmarks $\left(S_{\overline{3}} 37-41,43\right)$ are still visible on the lower spines of all partbooks except the contratenor and sexta vox, where they are obscured by a label with the Proske collection shelfmark. The word 'Novi' is visible at the top of the spine of the discantus, and was not quite effaced when the spine was painted. What is immediately notable about this convolute volume is that is shows so few signs of use: it is a reference copy. The pages are clean and their corners are sharp. I have demonstrated elsewhere that most extant exemplars of Ott's anthology show heavy signs of use, with many user-made annotations and corrections. ${ }^{107}$ Of the 100 motets, only a single one, Willaert's In diebus illis, has any signs of use in this exemplar (a correction in each of the contratenor, bassus, and quinta vox partbooks). The binding has the voice designation stamped in the centre panel in full in capital letters and blackened. There are seven Rollenstempel in the bindings. Roll A has three unnamed figures, from their attributes identifiable as King David (crown and lyre), St. Paul (sword and bible), and the resurrected Christ (with mandorla and hand raised in benediction), measuring $162 \times 19$ millimetres. Roll B has three unnamed busts: a woman wearing a bonnet, facing left; a man wearing a helmet, facing right; and a man wearing a hat, facing right, measuring c. $110 \times 11.5$ millimetres. Roll $\mathrm{C}$ has a naked man playing a curved horn with the bell curving over his head like a hat; two entwined serpents with horned human heads; and two serpents with crowns entwined around a sword. There are four generic rolls: $\mathrm{D}$ is flowers, $\mathrm{E}$ is leaves, $\mathrm{F}$ is plants, and $\mathrm{G}$ is an interlacing design. The watermark on the end-papers and other binders' leaves is a heraldic symbol: an orb on a shield. ${ }^{108}$

\footnotetext{
${ }^{106}$ This convolute is described in detail in Gustavson, 'Hans Ott', 809-13; the description here draws on, but also amends, that description.

107 See Gustavson, 'Hans Ott', 326-35.

${ }_{108}$ These watermarks are classified in the Wasserzeichen-Informationssystem as 'Wappen' (coat of arms), 'Gemeine Figuren' (common figures), 'Symbole'/Herrschaftszeichen' (symbols/ruler's insignia), 'Reichsapfel' (imperial orb), 'ohne weitere Belegung' ('without further assignment'), 'ohne Beizeichen ('without secondary mark'); they are between two chainlines and are similar to those on papers found in Goldberghausen (Baden-Württemberg) in 1558 and Linz in 1559. See reference numbers AT380o-PO-21784 and DE6300-PO-21785 at <https://www.wasserzeichen-online.de/ wzis/struktur.php?klassi $=103002006006001$ \&anzeigeIDMotif $=16643>($ accessed 19 November 2019). In the sexta vox, the watermark appears once in each of the six gatherings added during the binding process; each gathering is four leaves of quarto (that is, one sheet). One gathering is added at the front, with the first leaf as the paste-down; and five gatherings are added at the back, with the last leaf as the paste-down. A smaller version of the same watermark appears on the front free end-paper of the quinta vox. None of the other leaves added during binding has a watermark.
} 
S 3212 B.A.S., Walther's Gesangbuch, has a binding that, while not matching other music editions from the B.A.S., contains marks from some of the same tools. On the front and back binding of the tenor and discantus is a flower roll stamp, which Frisch convincingly associates with a binder in or near Salzburg, perhaps at Berchtesgaden, found also on the bindings of non-musical editions in the B.A.S. ${ }^{109}$ The same binder bound several of the B.A.S. music editions, including the three Stomius manuscripts. Nevertheless, as a bookbinder would have many clients, we must be cautious in drawing any conclusion other than that this volume was bound in or near Salzburg.

S 17 B.A.S. binds together the three volumes of Formschneider's edition of Heinrich Isaac's Choralis Constantinus. The bindings are similar to $\mathrm{S} \underline{3} 11$ above, and include Rollenstempel $\mathrm{A}$ and $\mathrm{B}$; there is also a flower roll which may be roll $\mathrm{D}$. The partbook names are stamped in capital letters and blackened. Of particular interest here is the watermark in the endpapers: it is a letter $\mathrm{P}$ with a Salzburg coat of arms, most similar to a paper dated $1556 .{ }^{110}$ These partbooks are not as well preserved as others: the spine of the discantus has been replaced, and the altus has a loose front cover and mould damage throughout.

S 38 B.A.S. originally bound together four volumes of tricinia in oblong octavo: the three-volume Montanus and Neuber series, and Le Maistre's Catechesis of 1563; it is argued above that Butsch removed the latter from the convolute to sell separately. The binding is of limp green-coloured vellum of a similar shade to the Egenolff partbooks of 1552 from the collection of Johann Georg von Werdenstein (1546-1608) at D-Mbs Mus.pr.46. There are faint fragments of white paint on the spine; the voice designations are given on the front cover in a white rectangle where the surface of the vellum has been cut and then heavily scraped: 'DISCAN9' [sic] and 'BASSVS.' The end-papers have no watermarks. On the front free end-paper is written 'Triciniorum select: Discantus [Bassus] || cum Chatechesi Musicali || S흥'. Of particular interest are the user additions to the bassus partbook. Although there is an illegible inscription on the title page of the bassus, there are theory notes on the front paste-down and, of particular interest, a diagram of the gamut on the back paste-down. This diagram is a diplomatic copy of the diagram on fol. A $4^{\mathrm{v}}$ of Stomius' treatise, Prima ad musicen instructio, published by Ulhart in Augsburg in 1537, providing evidence that the treatise was still used, at least in Stomius's circle, after 1563. That the Le Maistre was printed the year after Stomius's death is proof that this volume was not from his library.

S프 [covered by tab with Proske shelfmark] B.A.S. was a convolute of three Petrucci frottola editions. The second and third books of frottole are now in Regensburg, and the fourth book is now in Vienna. The reason why these editions were separated has been discussed above. The exemplar in Vienna, the last item in the convolute, was apparently separated for sale, while the binding remained with rest of the convolute, now in Regensburg. Boorman has measured the Regensburg exemplars as $168 \times 232$ millimetres, and the Vienna exemplar as $166 \times 229$ millimetres; ${ }^{111}$ this suggests that the two Regensburg exemplars and the Vienna

${ }^{109}$ Ernst von Frisch, 'Einbände des 16. Jahrhunders in und aus Salzburg', in Beiträge zum Rollen- und Platteneinband im 16. Jahrhundert: Konrad Haebler zum 80. Geburtstage...gewidmet, ed. Ilse Schunke, Sammlung Bibliothekswissenschaftlicher Arbeiten 46 (Leipzig, 1937), 125-33.

${ }^{110}$ Of the type described in Gerhard Piccard, Die Wasserzeichenkartei Piccard im Hauptstaatsarchiv Stuttgart, vol. 4, Wasserzeichen P (Stuttgart, 1977), section XVII, watermarks 571-77, all of Salzburg provenance, most similar to 575-77, especially 576, dated 1556; these marks are of the type described by Charles Briquet, Les filigranes: Dictionnaire historique des marques du papier des leur apparition vers 1282 jusqu'en 1600, 4 vols. (Leipzig, ${ }^{21923), ~ v o l . ~ 3, ~ w a t e r m a r k s ~ 8801-03 . ~}$

111 Stanley Boorman, Ottaviano Petrucci: A Catalogue Raisonné (New York, 2006), includes a detailed description, including page sizes, corrections and changes, and binding, of these editions: the exemplar of the fourth book in Vienna on 665, and of the second and third books in Regensburg on 681 and 673 respectively. 
exemplar were all from the same set, with the smaller size of the exemplar in Vienna presumably the result of trimming during the rebinding in the nineteenth century, as seen for example in the trimming of an early handwritten comment on the top left corner of fol. G8v. The sixteenth-century leather binding of the convolute in Regensburg is now detached, but the spine remains intact and is painted with the off-white oil paint found on B.A.S. volumes. ${ }^{112}$ Although the initial ' $\mathrm{S}_{\overline{3}}$ ' and the 'B.A.S.' of the shelfmark on the spine are visible, tabs with the Proske shelfmark cover the volume number; to judge from the position of the visible fragment of the number, it was a two-digit number, with the second number being an 8,9 , or o. On the top of the spine are remnants of a paper tab with a trace of writing; the tab was painted over, and so its attachment preceded the painting of the spine. The inscription on the title page is not in the hand that consistently wrote the $S \underline{3}$ shelfmark and the brief description that precedes it; as such, those details must have been written on the front free end-paper, which is now missing.

The evidence that the fourth book of frottole in Vienna was part of this convolute is circumstantial. It was acquired by the Hofbibliothek along with several items from the B.A.S. collection; the second and third books of frottole in Regensburg are from the B.A.S. collection. The evidence of the page sizes has been discussed above. There is other evidence to connect this fourth book with Salzburg. The final leaf of the volume has, on fol. G8 ${ }^{\mathrm{r}}$ next to Petrucci's colophon, the handwritten inscription 'Andreas Sueuulus hunc Italicę musicęs comparuit librum... 1522' ('Andreas Suevulus acquired this book of Italian music...1522'). ${ }^{113}$ The University Library of Salzburg retains a B.A.S. manuscript written in 1527 by Suevulus, who was Dean of the of monastery of St. Zeno, Bad Reichenhall (near Salzburg), and dedicated to O. Wolfgang Lueger, provost of the monastery; the later binding of the manuscript bears the coat of arms of the Salzburg Prince-Archbishop Maximilian Gandolph von Kuenburg (1668-87). ${ }^{114}$ On the verso of the final leaf of the fourth book of frottole, on fol. G8v', is a handwritten three-voice lied, 'O liebe Köchin', dated 1545; Grantley McDonald has suggested that the scribe may be Stomius. ${ }^{115}$ The insertion of a piece of music on a blank page in a printed edition or almost-full manuscript is consistent with what we know of Stomius. ${ }^{116}$ Overall, the evidence leads to the conclusion that the fourth book of frottole in Vienna also came from the B.A.S., and that it was in Salzburg by 1545.

\section{Bibliographical Observations on the Stomius Music Manuscripts}

Ernst von Frisch, in a study of Salzburg book bindings, identified six bindings from between 1538 and 1560 which included the letters 'B.A.S.' and the name 'A Geigen'. ${ }^{117}$

112 Boorman, 681, states that the spine is badly damaged and almost lost; the 'damage', however, is the oil paint found on the spines of all B.A.S. volumes. He does not note the B.A.S. shelfmark.

${ }^{113}$ I am grateful to Grantley McDonald for the transcription and translation. The spelling of the name differs from that given by Boorman, Petrucci, 665, who renders it 'suenulus'.

114 The shelfmark of the manuscript is M I 70; all information about the manuscript is taken from <http://www.ubs.sbg. ac.at/sosa/handschriften/mizo.htm> (accessed 17 November 2019).

115 See Grantley McDonald, 'The Library of Johannes Stomius', 68. This text does not appear in Norbert Böker-Heil, Harald Heckmann, and Ilse Kindermann, Das Tenorlied: Mehrstimmige Lieder in deutschen Quellen 1450-1580, 3 vols., Catalogus Musicus 9-11 (Kassel, 1979-86), and so this song is previously unknown.

${ }^{116}$ For example, the insertions on the end-papers of $S-3$, a composition on blank staves of fol. $A 2^{\mathrm{v}}-3^{\mathrm{r}}$ of $\mathrm{S}^{3} 16$, and on the final verso and rear end-paper of $S \underline{3} 35$.

117 Frisch, 'Einbände', $128-30$ and Plate 4. He notes that two of the bindings are stamped with the date 1538 . One is A-Su F II 56 (Frisch gives the shelfmark of the former Studienbibliothek: IV.3. G.78), which binds together Jacopo Sadoleto, 
Frisch suggests that this may be the name of the binder, but also notes that using such a large font size to stamp the name of the binder on the binding would be very unusual. The provenance catalogue of University Library of Salzburg, however, gives Geigen as the former owner of one of these editions, which I suggest is far more likely. ${ }^{118}$ Frisch's description of these bindings, which he argues were all made by one binder, matches the bindings of the three sets of Stomius manuscript partbooks in Regensburg. For example, Frisch's roll stamp with a deer used around the central panel matches the stamp on Reg I, which is also used around the central panel. Two of Frisch's bindings have the date 1538 , with quadratic periods, all coloured in with black ink, as does Reg I. One of the roll stamps described by Frisch is an angel, and Reg I has a roll stamp with an angel. One of the roll stamps on Reg III is a hunting scene, and one of Frisch's bindings also has a hunting scene. There are enough similarities to argue that the bindings of the three Stomius manuscripts were done by the same binder described by Frisch. ${ }^{119}$

The literature contains only fairly superficial descriptions of the physical characteristics of the three Stomius manuscripts, and so the following provides a detailed physical description of each of these sources:

S 3 10 B.A.S. (= Reg II). This set of three partbooks is described by a B.A.S. cataloguer immediately before the shelfmark on the front paste-down as 'Paschatij seu Missae in

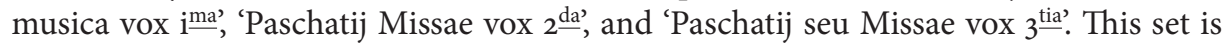
unlike $S^{2} 13$ and $S \underline{3} 37$, as Stomius was not the principal scribe, but added music to the manuscript on leaves left blank by other scribes, including the front and back pastedowns. Martin Staehelin differentiates six hands. ${ }^{120}$ The first of these, Staehelin's scribe I, who copied works 5, 6, 7, 9, and 11 (prima vox, fols. $3^{\mathrm{r}}{ }^{\mathrm{r}} 41^{\mathrm{v}}$ ), is the principal scribe both in terms of writing the most music and in being the first scribe to write in the partbooks. Stomius, whom Grantley McDonald identifies as Scribe V/VI, copied and, in some cases, squeezed short pieces of music into the empty spaces at the beginning and end of the manuscript and between the longer works (several mass ordinaries and a Salve regina). The rastrum used for the stave lines for these longer works was 15 millimetres, but that used for other compositions was narrower, mostly 10.5 millimetres (e.g. prima vox: before the first mass, fol. $43^{\mathrm{r}}$, back paste-down) though the rastrum used on fol. $42^{\mathrm{r}-\mathrm{v}}$ was 13 millimetres. As music has been entered onto the end-papers, those compositions were clearly added after binding.

This set of partbooks is physically unlike the other two. It is the only manuscript in portrait format, here an upright quarto. It is the only set of partbooks that does not align the staves horizontally and vertically by prick holes, but instead uses ruled vertical lines that go from the very top to the very bottom of each page from fol. $3^{\mathrm{r}}$ to fol. $64^{\mathrm{r}}$, marking the horizontal

In Pauli epistolam ad Romanos commentariorum libri tres (Lyon: Gryphius, 1536), and Berthold Pirstinger, Onus ecclesiae (Landshut: Weyssenburger, 1524); and the other is D-Eu (Universitätsbibliothek Eichstätt-Ingolstadt), Giovanni Bertachini, Tractatus de episcopo (Lugduni [= Lyon], 1533). D-Eu has two exemplars of the latter, and I do not know if the 'Geigen' exemplar is 04/1 D II 599 or 04/1 BO B I 39.

${ }_{118}$ [Cardinal] Matthäus Lang, Deß hochlöblichen Ertzstifts Saltzburgk Perckhwerchs Ordnung (Salzburg: Baumann, 1551); VD16 S 1519; A-Su II 5314 Rarum (Frisch gives the former Studienbibliothek shelfmark, 5314); see <http://www.ubs. sbg.ac.at/sosa/webseite/vorbesitzerg.htm> (accessed 15 April 2019).

119 Twenty-eight stamps found on early bindings in the University Library of Salzburg are described in Konrad Haebler, Rollen- und Plattenstempel des XVI. Jahrhunderts, 2 vols., Sammlung Bibliothekswissenschaftlicher Arbeiten, Ser. II, vols. 24-25 (Leipzig, 1928-29), vol. 25, 247-49. As they are described but not illustrated, the books on which they are found need to be examined to determine if any of these stamps are the same.

${ }^{120}$ Martin Staehelin, Die Messen Heinrich Isaacs, Publikationen der Schweizerischen Musikforschenden Gesellschaft, Series 2, vol. 28 (Bern, 1977), vol. 1, 77, n. 140; see also Haberkamp, Thematischer Katalog I, 204. 
boundaries of the staves but not their vertical alignment. Further, it has no original foliation, whereas the other two manuscripts have original foliation in red ink.

Structurally, each of these partbooks is gathered and bound in eights. As the format is upright quarto, the watermark is on the inner margin. Consistently throughout these partbooks, each gathering consists of two sheets, one forming leaves 1, 2, 7, and 8, and the other forming leaves 3-6. All sheets have the same watermark (appearing in two variants), an anchor not in a circle. ${ }^{121}$ The paper is thick and the watermark is faint; there is no agreement among those who have examined it as to exactly which watermark it is, but all proposed watermarks have a northern Italian provenance. ${ }^{122}$ In each partbook, the front and back end-paper consists only of the paste-down: there are no free leaves. The paste-down is bound in either after the first gathering for the front paste-down, or before the final gathering for the back paste-down.

Physical characteristics of the manuscript and the distribution of the scribal hands suggests that the manuscript was prepared and the pages ruled, and that at least Scribe I had completed his or her copying before the manuscript came into Stomius's possession. After it entered his possession, he and perhaps also others added compositions.

S노 13 B.A.S. (= Reg I). This set of five partbooks is described by a B.A.S. cataloguer immediately before the shelfmark on the front free end-paper as 'Musicalium diversorum Discantus [Altus / Tenor / Bassus / Vagans].'123 Although the number of pages, their dimensions, and the watermark of these partbooks have been given multiple times in the literature, ${ }^{124}$ there is as yet no detailed published description of their physical structure. Each partbook is in oblong quarto format, gathered and bound with eight leaves per gathering. The first leaf of the first gathering is blank. The music commences on the second leaf, which is foliated 1 , and so the foliation does not match the gathering structure: gathering 1 is foliated $\left[{ }^{*}\right]-7$ instead of $1-8$, gathering 2 is foliated $8-15$ instead of $9-16$, and so on. Each gathering is formed by two sheets, and we would expect to see that one sheet formed leaves $1,2,7$, and 8 , and the other sheet formed leaves $3,4,5$, and 6 . However, the watermark distribution makes it clear that this is not the case. As Mohr, Haberkamp, and Staehelin noted, only a single watermark type is found, but its distribution within each partbook has not been examined until now. ${ }^{125}$ Each sheet of paper in the set of partbooks, excluding the end-papers introduced during the binding, is watermarked. As expected, the watermark is paired, that is, it appears in two variants. ${ }^{126}$ As the partbooks are in oblong quarto format, the 'top' of the watermark is found at the upper part of one of the

${ }^{121}$ The watermark is centred on a chainline; the chainlines are approximately 28 millimetres apart.

${ }_{122}$ The watermark is Piccard, vol. 6, Wasserzeichen Anker (Stuttgart, 1978), Division I. Haberkamp, Thematischer Katalog $I, 209$, states that it is similar to watermarks 313-14, but I suggest that it is closer to watermarks 341-56. All of the watermarks 301-85 were produced in northern Italy (Piccard, Wasserzeichen Anker, 9). A similar watermark is found in Vladimir Mošin, Anchor Watermarks, Monumenta chartae papyraceae historiam illustrantia 13 (Amsterdam, 1973), Type It.I.f, nos 287-334; Mošin states that this type of watermark has a provenance of Fabriano in Italy (p. 14). Staehelin, Die Messen, vol. 1, 77, n. 138 and Haberkamp note that the mark is also similar to Briquet, Les filigranes, mark 444, which Briquet (p. 40) states is of Italian provenance.

${ }^{123}$ Except in the altus, where that leaf is missing and so this was written on the first leaf of the first gathering.

${ }_{124}$ Mohr, Die Handschrift, 19-20; Haberkamp, Thematischer Katalog I, 204; Herbert Kellman, ed., Census-Catalogue of Manuscript Sources of Polyphonic Music 1400-1550, vol. 3 (Neuhausen-Stuttgart, 1984), 96.

125 The watermark is a set of scales in a circle. Mohr, Die Handschrift, 20, reproduced but did not identify the watermark; Haberkamp, Thematischer Katalog I, 204, identified it as Briquet 2514. Staehelin, Die Messen, vol. 1, 77, n. 138, identified it as Briquet 2515. I have identified the watermark as Piccard, vol. 5: Wasserzeichen Waage, Division IX, similar to marks 1-2, which Piccard found in documents in Regensburg dated 1537; Division IX papers are from northern or central Italy (p. 11).

${ }^{126}$ See Allan H. Stevenson, 'Watermarks are Twins', in Studies in Bibliography: Papers of the Bibliographical Society of the University of Virginia 4 (1951-52), 57-91, 235. 
four leaves created from a particular sheet of paper, and the lower part of the watermark is found at the top of one of the other of the four leaves of the same sheet, while the other two leaves created from that sheet include no part of the watermark. As each gathering consists of two sheets of paper, each gathering should contain two upper parts and two lower parts, yet more than half of the gatherings have a different combination. For example, bassus gathering 2 (fols. 8-15) has four lower parts (sequentially on fols. 8-11) and no upper parts, but gathering 7 (fols. 48-55) has no lower parts but four upper parts (on fols. 48, 50, 52, and 54). For this to have occurred, a small number of sheets must have been picked up together and cut into two, and this process repeated numerous times, with the cut sheets added to a pile, so that we get a sequence of top halves of sheets, and then a sequence of bottom halves of sheets. This was done before either writing or binding commenced.

The binding of each partbook has an end-paper consisting of a paste-down and a free leaf; ${ }^{127}$ the front end-paper is bound in after the first gathering and the back end-paper is bound in before the final gathering. The end-papers in the discantus and bassus have no watermarks. The same broad type of watermark is found on the end-papers of the tenor (front and back free leaf, chainlines 34-35 millimetres apart), the quinta vox (front free leaf, chain lines 28 millimetres apart), and on the front free end-paper of $S \underline{3} 16$, the Musica di Eustachio Romano, which has an original leather binding stamped on the front cover with the date MDXXXII. The watermark is a letter $\mathrm{H}$ with a cross rising from the horizontal bar of the $\mathrm{H}$; the mark is between two chain lines. The most common location for this watermark identified in the Wasserzeichen-Informationssystem is Salzburg. ${ }^{128}$

Like S픈 37 B.A.S. (= Reg III), this set of partbooks aligns the staves on each page both vertically and horizontally by prick marks created by a tool that when pressed on the paper leaves a series of indentations, or in some instances holes, to indicate there the rastrum should begin and end as the scribe ruled the stave lines. This gives a neat manuscript with staves that are regular not only on each page, but also across each opening and on both sides of each leaf, so that the staves on one side of a leaf are not visible through the paper on the other side. The rastrum used for ruling these partbooks was 15 millimetres wide, and was used with great skill.

S프 37 B.A.S. (= Reg III). This set of four partbooks is described by a B.A.S. cataloguer immediately before the shelfmark on the front paste-down as 'Liber Musicalis vox prima [ $\left.2 \underline{\text { da }} / 3 \underline{\text { tia }} / 4^{\text {ta }}\right]$.' It is in sexto format, 133 millimetres high $\times 138$ millimetres wide, gathered and bound in sixes. The vox prima does not have an end-paper; instead, the first leaf of the first six-leaf gathering acts as the paste-down and the second leaf acts as the free leaf of the end-paper. The original foliation then begins on the third leaf with number 1 . This gathering is followed by eleven six-leaf gatherings (fols. 5-70), a four-leaf gathering (71-74), an eight-leaf gathering (75-82), and a six-leaf gathering (83-88, with 88 serving as the back paste-down). The secunda vox also has an irregular structure: the first gathering is of four leaves, with the first two acting as an endpaper; the original foliation begins on the third leaf with 1 . This is followed by two

\footnotetext{
${ }_{127}$ The front free end-paper of the altus is missing.

128 The Wasserzeichen-Informationssystem (<https://www.wasserzeichen-online.de>, accessed 17 November 2019) categorizes this mark as 'Buchstaben/Ziffern: ein Buchstabe: Buchstabe H: frei, mit Beizeichen: Kreuz: zweikonturig: ohne weiteres Beizeichen' ('letters/numbers: one letter: letter H: unattached, with additional mark: Cross: all parts of the mark in a double outline: without further additional marks'). This mark, when as here between two chainlines, is found in Salzburg (five different marks), Innsbruck (four), Prague (two), and one each in Linz, Egenburg, Bogenhofen, and Braunau, with dates ranging from 1522 to 1535.
} 
gatherings of six leaves, one gathering of four, and eleven gatherings of six leaves, with the final leaf serving as the paste-down. The tertia vox and quarta vox both have regular gatherings, with a structure in their first and last gatherings similar to that of the other partbooks.

Unlike the other two manuscripts, this manuscript has three papers. One paper has no watermark. ${ }^{129}$ The second paper has a watermark of an anchor in a circle surmounted by a six-pointed star. ${ }^{130}$ The third paper has a watermark of a crossbow in a circle surmounted by a fleur-de-lys. ${ }^{131}$ What has not been previously noted is that the watermarks are not intermingled but sequential: the partbooks commence with the anchor watermark and then change to the crossbow watermark. For example, the first six gatherings (fols. 1-34) in the vox prima and the first seven gatherings (fols. 1-36) in the secunda have anchor and unwatermarked papers; the rest of these partbooks have crossbow and unwatermarked papers. In the tertia, nine of the twelve gatherings are unwatermarked, precluding the identification of a pattern, but the watermarks are consistent with this. The watermarks suggest a structure which relates to the contents of the partbooks. Compositions 2-14 are written on fols. $1^{\mathrm{r}}-34^{\mathrm{r}}$ in three of the partbooks, and $1^{r}-33^{v}$ in the quarta. The watermark changes after that gathering. In the three partbooks with more than thirty-four leaves (i.e., all except the quarta), fol. $35^{\mathrm{r}}$ is blank. Composition 1 has been added later to what was in effect the front free end-paper, with stave lines drawn with a different rastrum. Compositions 15 and 16 have been added on fol. $34^{\mathrm{v}}\left(34^{\mathrm{r}}\right.$ in the quarta), with what appears to be the same rastrum used for the stave lines drawn for composition 1 . This suggests that these partbooks began with a set of gatherings on which compositions 2-14 were written commencing on fol. $1^{\mathrm{r}}$; later, lines were ruled on the recto and verso of the leaf preceding fol. 1 and on fol. $34^{\mathrm{v}}$ (fol. $34^{\mathrm{r}}$ of the quarta) of each partbook and compositions 1, 15, and 16 entered; additional gatherings on a different paper were then added to accommodate compositions 17 onwards.

Here it may be possible to reconstruct the layers of repertoire which Proske identified in these partbooks and hence individual shelfmarks: B 220 may have been intended to represent the two four-voice compositions added at the beginning and end (numbers 1 and 52); B 221 the four-voice compositions (numbers 2-14); and B 222 the bicinia and tricinia (numbers 15-51).

\footnotetext{
129 As a significant number of gatherings have no watermark, this suggests a possibility that the partbooks may be in duodecimo format bound and gathered in sixes, but the size of the leaves and the position of the watermark rule out this possibility.

${ }_{130}$ The watermark is Piccard, vol. 6: Wasserzeichen Anker (Stuttgart, 1978), Division V, similar to marks 181-361; Piccard states that all of these papers were made in Northern Italy in the vicinity of Venice (p. 9). The mark is centred on a chainline. Haberkamp, Thematischer Katalog I, 211, suggests that the watermark is closest to 303-6, and that it is also similar to Briquet, Les filigranes, watermark 490. Staehelin, Die Messen, vol. 1, 77, n. 138 however suggests that it is similar to Briquet watermark 481; I suggest that of the Briquet marks it is closest to watermark 495. A similar watermark is found in Mošin, Anchor Watermarks, Type It. II.2A.d, Nos. 642-87.

${ }^{131}$ This second watermark is not noted by Haberkamp, Thematischer Katalog I. Staehelin, Die Messen, vol. 1, 77, n. 138 , notes that it is similar to Briquet, Les filigranes, watermark 762, of northern Italian provenance. My examination identifies the watermark as similar to Piccard, vol. 9: Werkzeug und Waffen (Stuttgart 1980), Division XI, watermarks 2256-58 and 2390-98; these papers were made in central and northern Italy, and northern Italy respectively (p. 13). This style of watermark is also found in David Woodward, Catalogue of Watermarks in Italian Printed Maps ca. 1540-160o, Biblioteca di bibliografia italiana 141 (Florence, 1996), 132 mark 216 (dated 1542 to 1554).
} 


\section{Conclusion}

This study has given a glimpse into the music collection of the former Bibliotheca aulica Salisburgensis and its subsequent dispersal. This provides a way forward to identify more books from the collection in other libraries, and to further develop our understanding of the original structure and content of the music collection in the B.A.S. Although it is unlikely that more printed music from the B.A.S. will be identified in the collection of the Österreichische Nationalbibliothek, a systematic examination of the Proske collection of the Bischöfliche Zentralbibliothek in Regensburg may result in further identifications. ${ }^{132}$ I suspect strongly that more printed music from the B.A.S. might be identified in the British Library by a first-hand examination of all editions common to both the Seltene Notendrucke and the Asher and Co. invoice. An examination of holdings in other libraries for editions listed in the Seltene Notendrucke may reveal further B.A.S. exemplars. The manuscripts, however, are a very different problem, as there is no systematic way of identifying them. Although there are no extant library catalogues from the B.A.S., the early to mid-nineteenth century library catalogues from the Salzburg Studienbibliothek (now the Universitätsbibliothek) remain to be explored for clues, as do Salzburg archives. ${ }^{133}$ Given the apparent similarities with the dispersal of the early music collection of St. Anna, Augsburg, in the mid-nineteenth century, the continuing research by Richard Charteris on the history of that collection may lead, by analogy, to further discoveries of material from the B.A.S. ${ }^{134}$ Nevertheless, this first step towards identifying and examining the polyphonic music formerly in the B.A.S. has done three things. Firstly, it has provided further context for the research, discoveries, and insights of Grantley McDonald and Paul Kolb on the Stomius manuscripts. Secondly, it gives insight into the development of collections of early music during the mid-nineteenth century. And finally, it gives us the first, albeit incomplete, overview of the music collection of the former Bibliotheca aulica Salisburgensis.

${ }_{132}$ Haberkamp and Reutter were cataloguing manuscripts, not printed music, and although they mention the shelfmarks of two multi-volume sets of printed music in passing (both of which had a clear B.A.S. shelfmark on their spine), it was not the purpose of their study to examine the end-papers and title pages of printed music, and so a more detailed investigation of the printed music is needed (as indicated by their not having identified B 3335 despite the spine being painted and having a B.A.S. shelfmark). There are also purchases from Butsch intermingled with Proske's Regensburg collection (the shelfmark A.R. was used by Proske to indicate a Regensburg provenance); for example, an incomplete exemplar of the Missae tredecim (RISM 15392) formerly catalogued at C $62 \mathrm{a}$, which indicates that it was purchased from Butsch, has been re-catalogued as A.R. 90-92 so that it sits on the shelf next to the exemplar of the Missae tredecim at A.R. 90-92b. Importantly, most music theory titles in Seltene Notendrucke are also found in Proske's collection, but I am not aware that anyone has yet examined them; I will do so in 2020.

${ }_{133}$ Elisabeth Giselbrecht, “Musica transalpina”: Venezianische Musikdrucke im Salzburg der Frühen Neuzeit', in Von Venedig nach Salzburg: Spurenlese eines vielschichtigen Transfers, ed. Gerhard Ammerer, et. al. (Vienna, 2015), 107-22 at 121, refers to the inventory of the books of Johann Rotmair at Salzburg, Landesarchiv GA XXV.R.29; McDonald, 'The Library of Johannes Stomius', 81, notes that this inventory included the 'Harmoniae poeticae Pauli Hofhaimer, $4^{\text {or }}$ Vocum.' (fol. $70^{\text {r }}$ ), which may have been from Stomius's library; if so, this might suggest that other music books from Stomius's collection may also be in the inventory. I am grateful to the Salzburg Landesarchiv for sending me scans of several pages of this inventory.

${ }_{34}$ Richard Charteris, An Annotated Catalogue of the Surviving Early Music Editions Once Owned by St Anna Augsburg and Adam Gumpelzhaimer, in press. He also has a monograph on the Asher invoice to the British Museum, A Rediscovered Collection of Continental Early Music Editions in The British Library, in preparation. He has kindly informed me that he has not to date identified any editions on the Asher invoice as having a B.A.S. provenance other than the two that I had also identified (email of 18 April 2020), and so any further identifications will require evidence other than B.A.S. bindings and shelfmarks, for example the presence of Stomius' hand. 


\section{Abstract}

The University Library of Salzburg, which holds much of the former Archiepiscopal Court Library of Salzburg (Bibliotheca aulica Salisburgensis, hereafter B.A.S.), contains almost no early polyphonic or instrumental music. Nevertheless, recent research has determined that the B.A.S. included a corpus of printed and manuscript polyphony from the first half of the sixteenth century. The present paper examines the dispersal of this collection, which began in the 1840 s, and traces the location of the identifiable polyphonic music books from the B.A.S. by following their transfer through the rare book trade in the mid-nineteenth century. This process has resulted in identification of an additional twenty-two extant printed editions, thereby increasing the total number of identified extant printed editions with a B.A.S. provenance from nine to thirty-one. The paper then, as far as currently possible, reconstructs and discusses the polyphonic music collection of the B.A.S. 
